\title{
Gender Diverse Portfolios as New Asset Class
}

\author{
Ming-Tsung Lin and Ser-Huang Poon*
}

August 9, 2017

\begin{abstract}
This paper studies market-traded equity portfolios that are constructed based on a minimum number of female board members and/or a target female work force ratio. Using the top 1,000 US firms from 2002 to 2015 as the tradable asset universe, we replicate and backtest five gender diverse portfolios. We find that these portfolios have smaller idiosyncratic risks and that their constituent firms have better CSR (Corporate Social Responsibility) rating. Consistent with previous research findings on CSR stocks, these gender diverse portfolios also have a smaller downside risk. From the portfolio's risk-return performance and their social policy implication, we argue that that these gender diverse portfolios constitute a new asset class.
\end{abstract}

Keywords: Board Gender Diversity, Female Corporate Leadership, Corporate Governance, Corporate Social Responsibility.

JEL Classification: G12, G24, C22, C23, C24, C31

*Ming-Tsung Lin (ming-tsung.lin@dmu.ac.uk) is at De Montfort University, UK. Ser-Huang Poon (ser-huang.poon@manchester.ac.uk and corresponding author) is at the University of Manchester, Alliance Manchester Business School, UK.

Acknowledgment: Funding from Alliance Strategic Research Grant is gratefully acknowledged. We are grateful to Kevin Aretz, Jennifer Bender, Michael Brennan and Richard Lacaille for helpful suggestions and comments, and Yiping Chen for excellent research assistance. We also thank seminar participants at Essex Business School and Global Science and Technology Forum in Singapore for helpful suggestions. All remaining errors are our own. 


\title{
Gender Diverse Portfolios as New Asset Class
}

\begin{abstract}
This paper studies market-traded equity portfolios that are constructed based on a minimum number of female board members and/or a target female work force ratio. Using the top 1,000 US firms from 2002 to 2015 as the tradable asset universe, we replicate and backtest five gender diverse portfolios. We find that these portfolios have smaller idiosyncratic risks and that their constituent firms have better CSR (Corporate Social Responsibility) rating. Consistent with previous research findings on CSR stocks, these gender diverse portfolios also have a smaller downside risk. From the portfolio's riskreturn performance and their social policy implication, we argue that that these gender diverse portfolios constitute a new asset class.
\end{abstract}

Keywords: Board Gender Diversity, Female Corporate Leadership, Corporate Governance, Corporate Social Responsibility.

JEL Classification: G12, G24, C22, C23, C24, C31 


\section{Gender Diverse Portfolios as New Asset Class}

\section{INTRODUCTION}

Gender diversity is a key policy hotly debated around the world. Numerous government legislation has been introduced to encourage firms to improve board gender diversity and to increase the female work force. Board gender diversity is typically promoted through "equality of opportunity" or through "equality of outcome" (Watson, 1995). Belgium, France, Germany $!_{1}^{1}$ Iceland, India, Israel, Italy, Norway $\left.\right|^{2}$ and Spain currently have legislated quotas for women on corporate boards of publicly listed companies (World Bank Group, 2015); this is an example of "equality of outcome". For the latter, fifteen countries, including the UK, have included in their corporate governance codes requiring companies to "comply or explain" gender diversity board composition (Terjesen et al. 2015). While gender diversity is improving over the years, gender equality is still a distant goal. According to the European Commission, the average female board ratio for the largest publicly listed firms among the 28 EU Member States was merely $18.6 \%$ in 2014. Outside the European union, female board ratio is much lower. Figure 1 presents female board ratio from BoardEx as of April 2015 in four region/country groups: EU, UK, US and the rest of the world (RoW), and further divided into ten sectors. Not surprisingly, EU with its strong legislation has the highest average female board ratio across all sectors (from $18 \%$ for "Materials" to $23 \%$ for "Consumer Staples") $]^{3}$ In contrast, RoW has the lowest female board ratio at around $10 \%$ across all sectors. Female board ratio is higher in "utility" and "consumer", but lower in "Energy", "Materials", and "Telecommunication Services". It is important to note that the highest female board ratio for any sector and in any region is less than $25 \%$, indicating that the corporate boardrooms around the world are very much dominated by men.

\footnotetext{
${ }^{1}$ Germany made it compulsory from 2015 for large firms to commit to at least $30 \%$ of nonexecutive female members on the board of directors. See https://www.theguardian.com/business/2015/mar/ 06/germany-gender-quota-legislation-boardroom-law-women

${ }^{2}$ Since 2003, Norwegian firms are required to have at least $40 \%$ representation at the board level for each gender. See Bertrand et al. (2014) for comprehensive analyses on this legislative impact on Norwegian firms.

${ }^{3}$ Some information about global legislation on board diversity can be found on Harvard Law School Forum on Corporate Governance and Financial Regulation (Gender Parity on Boards Around the World, https: //corpgov. law.harvard.edu/2017/01/05/gender-parity-on-boards-around-the-world/).
} 
Apart from the social debate, some questioned the value added that female leadership brought to the boardroom. Research findings to date are inconclusive, implying that board gender diversity does not lead to superior/worse firm performance, or add to/destroy shareholder value. $4^{4}$ Bohren and Strom (2010) find that gender diversity improves corporate financial performance among the listed companies in Oslo Stock Exchange (OSE) in Norway. Dezsö and Ross (2012) examine constituent firms in S\&P 1500 index and find that female managers bring informational and social diversity benefits to corporate performance (e.g. Tobin's Q, ROA, and ROE), if the firm also has a high proportion of R\&D expenses (scaled by the value of total assets). Garcia-Meca et al. (2015) document a positive gender impact on firm's performance in the banking sector. Kang et al. (2010) find positive abnormal stock returns in Singapore on the announcement of appointment of women directors who assume independent board positions but not for the appointment of women CEOs. Lyngsie and Foss (2017) study firm's self-reported counts of new business opportunities in Denmark. They find a connection between successfully launched business and the proportion of female in the top management team. They argue that gender diversity in top management promotes "thinking out-of-box". But Adams and Ferreira (2009) find that board gender diversity decreases corporate value of US firms. Carter et al. (2010) find that gender diversity does not have a significant impact on corporate performance among the constituents of the S\&P 500 index. Chapple and Humphrey (2014) report no relationship between gender diversity and Australian firm return. Gregory-Smith et al. (2014) study FTSE firms but find no relationship between the proportion of female directors and the firm's ROA or ROE. Sila et al. (2016) find gender diversity does not affect board's risk-taking, but the firm's risk-taking affects the choice of director's gender. Finally, Abdullah et al. (2016) examine board gender equality and corporate performance in Malaysia, but find mixed results; a positive relationship for ROA and a negative relationship for Tobin's Q. They attribute this mixed effect to different performance indicators, firm ownership, and board's structure.

Notwithstanding the equivocal empirical evidence in the literature, a number of gender diverse portfolios have been launched in recent years. The exchange-traded fund (ETF ticker: SHE) based on SSGA (State Street Global Advisors) Gender Diversity Index was

\footnotetext{
${ }^{4}$ See Adams et al. (2015) editorial note.
} 
launched in 2016 $5^{5}$ while Barclay's Women in Leadership (ETN ticker: WIL) was launched earlier in 2014. The success of these market-traded gender diverse equity portfolios could potentially trigger a second wave of social change even without any new legislation: if more investment is drawn to these portfolios, more mutual funds and ETF will increase their investment in gender diverse firms, and more firms will become more gender diverse just to join the bandwagon or to make themselves more attractive for portfolio selection. As most of these gender diverse equity portfolios are launched in recent years, to the best of our knowledge, no study has conducted any analyses or backtests on these portfolios. The lack of research efforts reflects the difficulty in tracing appointment history at board and senior management levels. Our research fills this gap in the literature by providing a detailed analysis of the portfolio risk-return profile and by characterizing the constituent firms included in these portfolios. Our research findings will facilitate informed investment decisions.

To achieve aforementioned goals, in this paper, we focus on the most liquid and tradable US stocks typically chosen as constituents of these market traded gender diverse portfolios. We study, in particular, SSGA's SHE, Barclay's WIL, MSCI's Women on Board Index (WOB), Morgan Stanley's Parity Portfolio (MSParity), and a portfolio that conforms to a US campaign, 2020 Women on Board (US2020, hereafter) 6 Using board member and senior manager information in BoardEx, we create mimic portfolios for each of these gender diverse portfolios and backtest their risk-return performance from 2002 . By reversing the asset selection criteria of SHE, we created HE as SHE's counterpart (with zero to $5 \%$ female board ratio) in order to compare portfolio performance from the two ends of the gender diversity spectrum. We apply Carhart four factor model to test for portfolio alphas. We do not find any significant abnormal return for all portfolios. This finding is consistent with Chapple and Humphrey (2014) and is in line with the fact that the US stock market is efficient. However, we do find portfolio idiosyncratic risk is smaller for all gender diverse portfolios than HE. Moreover, we find this "idiosyncratic risk vs. female board ratio" relationship has a U-shape pattern, suggesting that there is an optimal level of female board ratio which translates to three female board members in a typical board size of 10 members.

\footnotetext{
${ }^{5}$ See article in Business Wire (http://www.businesswire.com/news/home/20160307005890/en/ State-Street-Global-Advisors-Launches-Gender-Diversity) for detail.

${ }^{6}$ See Sonnabend (2015) for more detail.
} 
How is board gender diversity linked to a smaller stock idiosyncratic risk? Some of the previous studies may have provided possible explanations. Adams and Ferreira (2009), among others, argue that female board members are more likely to join monitoring committees; therefore, a more gender diverse board tends to lower business risk. In this paper, we test the relationship between board gender diversity and stock idiosyncratic risk through firms' corporate social responsibility (CSR) performance. We use firm's CSR score obtained from MSCI KLD ESG database as instrumental variables for female board ratio after controlling for firm characteristics. We find that these CSR instrumental variables for female board ratios have a negative relationship with firm's idiosyncratic risk. Our findings confirm that connection between gender diverse board and firm's reduced idiosyncratic risk is through the "Corporate Social Responsibility" channel. There is established literature claiming that some investors invest in firms that are more socially responsible, because these firms provide "insurance-like" benefits (Godfrey, 2005, Godfrey et al. 2009; Koh et al., 2014).7] Our paper contributes to this thread of literature by linking women board representation and corporate social responsibility, and by providing evidence that this link extends to a reduced idiosyncratic risk for stocks. In the last part of our analyses, we conduct robustness test if board gender diversity indeed has an impact on firm's CSR performance. We provide evidence that board gender diversity improves corporate social responsibility, and there is no reverse causality. When we further investigate the sub-components of the CSR score, we find that gender diverse board helps to reduce concerns among "Diversity" and "Governance" aspects of CSR. These results extend the findings in Adams and Ferreira (2009), and are consistent with findings in Marquis and Lee (2013) that female board members contribute to corporate philanthropy.

\section{DATA}

This section details the data sample used in this paper and the formation of our gender diverse equity portfolios. Since the main objective of this paper is to backtest markettraded equity portfolios, stock investability and liquidity are important considerations

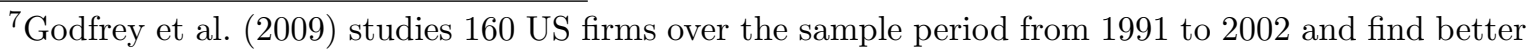
CSR firms' CAR suffered less during negative impact events (e.g. legal/regulatory actions arising from health/safety violations as reported in the Wall Street Journal).
} 
for our choice of the stock sample universe. Hence, we use firm size as a proxy for investability. We choose not to use stock trading volume because stock trading volume can be volatile and very sensitive to negative news (Brennan et al., 2013). In contrast to stock trading volume, firm size, represented by firm's market capitalization, is more stable. In addition, large firms are more likely to be investment targets, especially for institutional investors.

We use Datastream and Compustat to identify top 1,000 US firms with the largest market capitalization value. The selection is repeated each year and therefore we have 14,000 firm-year observations with 1,951 unique firms over the 14-year period from 2002 to 2015.8 We follow as close as possible the firm selection rules documented in SSGA's description of their Gender Diversity Index, the underlying index of their SHE ETF 9 The same 1,951 firm universe is used to form all other gender diverse portfolios to aid comparisons. All our gender diverse portfolios are value-weighted portfolios.

For the 1,951 firms in our stock universe, we collate the board executive and senior manager information from BoardEx, and corporate social responsibility information from MSCI KLD ESG databases. Unfortunately, BoardEx does not provide board information for some listed firms. Therefore, for any company that cannot be traced in BoardEx, we replace it with another firm that has the next highest market capitalization value, making sure that we have 1,000 firms in each year. In total, 33 firms were replaced due to no record in BoardEx, with an average of 6 missing firms per year (with the minimum of one unmatched firm in 2015, and a maximum of 10 unmatched firms in 2002). Over the 14-year period from 2012 to 2015, there are 33,593 senior managers, and 14,761 directors in our sample.10

Next, we detail how each gender diverse portfolio is constructed.

SHE and "HE": According to State Street Global Advisors (SSGA), the SHE ETF,

\footnotetext{
${ }^{8}$ Following SSGA's SHE, the portfolio's rebalanced dates are on 15th July of each year, except for 2015 when the rebalanced date is on 15th April as our BoardEx historical data terminates on 24th April, 2015 .

${ }^{9}$ The selection rules are detailed in https://www.ssga.com/investment-topics/ general-investing/2016/SSGA-Gender-Diversity-Index-Methodology ·pdf

${ }^{10}$ For the 1,951 firms selected, 392 firms have missing appointment dates at board level, and 1,155 firms have missing appointment dates at senior management level. As some of the firms have missing appointment dates for both board members and senior management, the total number of firms with some missing appointment information is less than the sum of 392 and 1,155. The individuals with missing appointment dates (about $0.2 \%$ of the population) are omitted in the calculation of female (board) ratio.
} 
based on its Gender Diversity Index, is designed to track the performance of US largecapitalization firms that are leaders within their respective industry sectors in advancing women through gender diversity on their boards of directors and in senior leadership positions. A stock is selected if it is among the highest ranked in its sector in terms of female ratio among senior managers, directors, or executives, and that the firm has a female CEO, or a female chairperson, or at least one female board member 11 The highest ranking stocks, within each sector, are selected till the total market capitalization of the selected stocks reaches the $10 \%$ market capitalization of that sector 12 For comparison, we created HE equity portfolio by choosing the firms with the lowest female ratio within each sector till the total market capitalization of the selected stocks reaches the $10 \%$ market capitalization of that sector.

MSParity: Morgan Stanley Parity Portfolio (MSParity) focuses specifically on increasing female board representation with the minimum of three female directors. The portfolio selection criteria also include several quantitative indicators such as free cash flow, profitability, and valuation, and some qualitative indicators such as business model and adaptability, management strength, and innovation strength. Unfortunately, we do not have access to the details of these indicators; hence, we simply use a minimum of three female directors to form our synthetic MSParity portfolio.

WIL: Barclay's Women in Leadership (WIL) is a debt-related ETN (Exchange Traded Note) that tracks a portfolio of firms with a female CEO or with women making up at least one-fourth of the board of directors. To be included in the portfolio, a firm must meet specific market capitalization and trading volume thresholds. Our goal here is not to value the ETN but to track the index portfolio. To mimic WIL, we select a firm if it has a female CEO, or it has more than $25 \%$ of female representation on the board of directors.

WOB: To be included in MSCI's Women on Board (WOB), a firm must satisfy all three criteria: (i) At least three female board members or two female board members if one of them is in a current leadership role (e.g., CEO, co-CEO, Chair, Co-Chair, Executive

\footnotetext{
${ }^{11}$ Here, CEO includes also deputy CEO, co-CEO, but excludes division CEO and regional CEO. Chairperson includes also vice chairperson, deputy chairperson, but excludes committee chairperson.

${ }^{12}$ The sector information is extracted from Compustat. The Compustat industry classification is identical to GISC except that it lists real estate firms separately. To be consistent with GISC, we group 'Real Estate' as part of 'Financial'.
} 
Chair, Lead Director, or CFO); (ii) Percentage of women on board must exceed the national average or 50\%; and (iii) Excludes firms facing Severe and Very Severe "Labor Rights - Discrimination and Workforce Diversity" Controversy Scores. For simplicity, we create our version of WOB using criterion (i) above, and (ii) the percentage of women on board must exceed the sample average on the portfolio's annual re-balance date.

US2020: According to Sonnabend (2015), the "2020 Women on Boards" campaign advocates a minimum of $20 \%$ of women on corporate boards. To form our US2020 portfolio, we include all firms with $20 \%$ or higher female board ratio.

Table 1 reports the board diversity statistics for all five gender diverse portfolios and HE. The average board size is more than 9 board members, and the average number of female board members is just 1.19 (or 12\%) over the sample period from 2002 to 2015 . When we look at the board statistics across all portfolios, we do not find huge differences in board size. For all gender diverse portfolios, the average female board size is between 10 and 12 board members, while the average board size for HE, the male dominated counterpart, is slightly smaller (9 members). In contrast, there is a clear difference in female board representation between $\mathrm{HE}$ and the other five gender-diverse portfolios. The average number of female board members is about 3 (or 30\%) across all gender diverse portfolios, but less than 1 (or $2 \%$ ) for HE.

Figure 2 plots the female board ratio for SHE and HE. It is clear that SHE has a much higher female board ratio than HE throughout the sample period. Interestingly, both portfolios have increasing female board ratios over time, but SHE $(32.15 \%-25.18 \%=$ $6.97 \%)$ has a higher level of increase than $\mathrm{HE}(4.42 \%-1.6 \%=2.82 \%)$.

We match our 1,951 firms with their CSR scores obtained from the MSCI KLD ESG database. The ESG scores in KLD are provided in seven main categories: Environment (ENV), Community (COM), Human Rights (HUM), Employee Relationship (EMP), Diversity (DIV), Product (PRO), and Corporate Governance (GOV). The combined score (ALL) is the sum of the category scores. For each category, KLD reports the number of strengths and concerns separately and its category score is calculated as strengths minus concerns under each category. Since our objective is to study the relationship between female board members and their impact on corporate social responsibility, there is a potential endogeneity issue if our KLD ESG score contains board gender diversity as well. 
Hence, we removed the board diversity score from DIV, and recalculate ALL and DIV accordingly.

KLD ESG score is widely used in studies of corporate social responsibility. Choi and Wang (2009), Hillman and Keim (2001), and Mattingly and Berman (2006) use the aggregate CSR score (or ALL in this paper) to study the individual firm's CSR performance. Some studies focus on the subset of the category scores from specific aspects of corporate social responsibility. For example, Bear et al. (2010) study firm's technology strength $(\mathrm{PRO}+\mathrm{GOV}+\mathrm{EMP})$ and institutional strength $(\mathrm{COM}+\mathrm{DIV})$. Our paper extends these studies as we study both category strength and concern separately and also their aggregate.

Table 2 reports the descriptive statistics of the KLD ESG strength, concern, and overall scores for the 1,951 firms over the period from 2002 to 2015 . The combined score is negatively -0.11 , due to the average concern measure (2.12) being larger than the average strength measure (2.02). The overall CSR improved over the two sub-sample periods. The average strength increased from 1.61 to 2.41 over time, while the average concern reduced from 2.22 to 2.04 .

Table 3 reports the sector average composite scores (ALL), standard deviations and the number of firm years in each sector. Some sectors such as "Energy" and "Materials" have comparatively lower CSR scores (-1.34 and -0.81, respectively), while "Consumer Staples" and "Financials" have the highest scores (0.39 and 0.13 , respectively). It is interesting to note the similar sector pattern with the sector female board ratio presented in Figure 1. The statistics in Table 3 suggest sector difference in CSR performance. Therefore, we add sector dummies to control for sector fixed effect in subsequent analyses.

\section{HYPOTHESES AND RESEARCH DESIGN}

\section{Portfolio Risk-Return Characteristics}

Most of the previous studies have investigated the impact of gender diverse board on corporate performance in terms of firm's profitability and business risk. Our first research objective here is to investigate if investing in market traded gender diverse portfolios 
generates abnormal return to shareholders 13 Using Carhart four-factor model, Chapple and Humphrey (2014) find that, among S\&P-ASX 300 constituents, some sector-based portfolios such as "Basic Materials" have positive abnormal return, while others such as "Consumer Services" do not. Compare with Chapple and Humphrey (2014), our focus is on the risk and returns of market-traded portfolios of stocks with gender diverse board and senior management. In particular, we also study the portfolio's idiosyncratic risk, namely portfolio's residual volatility after adjusting and controlling for the known systematic risks that are priced. We formulate our first set of hypotheses as follows:

H1: Investing in gender diversity is beneficial; stock market reacts positively if firms have gender diverse board and senior management.

We use the portfolios constructed in the previous section (including a male dominated counterpart created by us) to test if gender diverse portfolios produce higher return and smaller portfolio risk. Specifically, we test the following two hypotheses:

H1a: Gender diverse portfolios generate higher risk-adjusted returns than HE, and

\section{H1b: Gender diverse portfolios have lower idiosyncratic risks than HE.}

We use the Carhart four-factor model to test for abnormal return and to estimate portfolio idiosyncratic risk. For each portfolio, $p$, we run a time-series regression by

$$
\begin{aligned}
\text { ExRet }_{p, t}=\alpha_{p} & +\beta_{p}^{M k t R f}\left(R_{M, t}-R_{f, t}\right)+\beta_{p}^{S M B} S M B_{t}+\beta_{p}^{H M L} H M L_{t} \\
& +\beta_{p}^{M O M} M O M_{t}+\varepsilon_{p, t}
\end{aligned}
$$

where $\operatorname{ExRet}_{p, t}$ is the monthly portfolio excess return in month $t, R_{M}-R_{f}$ is the market risk premium, $S M B$ is small-minus-big or the size premium, $H M L$ is high-minus-low or the growth premium, and $M O M$ is momentum. A positive and statistically significant $\alpha$ indicates the existence of a superior risk-adjusted return conditioned on the four Carhart risk factors ${ }^{14}$ Portfolio idiosyncratic risk $\sigma_{\varepsilon, p}$ is defined as the standard deviation of the residuals $\varepsilon_{p, t}$ in Equation (1).

To test $H 1 a$, we calculate portfolios' time-series risk-adjusted excess return by $\alpha_{p, t}=$

\footnotetext{
${ }^{13}$ Chapple and Humphrey $(2014)$ strongly argue that such a portfolio approach reduces typical endogeneity issue related to test on gender diversity and firm's performance.

${ }^{14}$ Monthly Carhart risk factors are obtained via WRDS.
} 
$\alpha_{p}+\varepsilon_{p, t}$, and run paired Student's $t$-test on $\alpha_{p, t}$ between portfolios. To test $H 1 b$, we use Chi-square variance test to investigate if $\varepsilon_{p, t}$ is significantly different between portfolios.

Ang et al. (2006) and Ang et al. (2009) argue that firm's idiosyncratic volatility is priced cross-sectionally. They report a significant difference in stock returns of portfolios sorted by the standard deviations of the residuals from the Fama-French model. Following these studies, we further explore the volatility-gender relationship at the firm-specific level for the sample of 1,951 firms. For each year $t$, we run individual Carhart four-factor model on the monthly returns on each stock:

$$
\begin{aligned}
\text { ExRet }_{i, m}=c_{m} & +\beta_{i, t}^{M k t R f}\left(R_{M, m}-R_{f, m}\right)+\beta_{i, t}^{S M B} S M B_{m}+\beta_{i, t}^{H M L} H M L_{m} \\
& +\beta_{i, t}^{M O M} M O M_{m}+\varepsilon_{i, m},
\end{aligned}
$$

Then, firm $i$ 's year $t$ idiosyncratic volatility is calculated as $\operatorname{IdioV} \operatorname{Vol}_{i, t}=\sqrt{12} \times \operatorname{std}\left(\varepsilon_{i, m}\right)$, where $\varepsilon_{i, m}$ is the residual term from Equation (2) in year $t$. Then, we regress firm's $I_{d i o V} l_{i, t}$ on lagged board gender diversity proxy using Fama-MacBeth regression below:

$$
\begin{aligned}
\text { IdioVol }_{i, t}=c & +\alpha_{1} \times \beta_{i, t}^{M k t R f}+\alpha_{2} \times \beta_{i, t}^{S M B}+\alpha_{3} \times \beta_{i, t}^{H M L}+\alpha_{4} \times \beta_{i, t}^{M O M} \\
& +\alpha_{5} \times \text { FemaleRatio }{ }_{i, t-1}+e_{i, t}
\end{aligned}
$$

where $\beta_{i, t}^{\bullet}$ are the year $t$ beta risk sensitivity obtained from Equation (2), and Female Ratio $o_{i, t-1}$ is the 1-year lagged female ratio. Here, we use two versions of female ratios: one includes female board members only, and the other one is calculated based on female board members and female senior management.

Furthermore, previous studies report a non-linear relationship between board gender diversity and corporate performance. First, there is a threshold effect where a critical mass of three female board members is often quoted; unless the number of female board members is three or more, the presence of female director(s) alone has no impact on corporate decision ${ }^{15}$ Joecks et al. (2013) describe the critical mass of three as a "magic" number, when they find a U-shape pattern between the ROE (return on equity) and the level of corporate gender diversity. Kanter (1977) classifies gender diversity intensity in

\footnotetext{
${ }^{15}$ For example, Joecks et al. (2013) and Konrad et al. (2008) study listed German firms and find the critical mass for women directors is $30 \%$ or $20-40 \%$ or three women directors; Torchia et al. (2011) study Norwegian firms and find the critical mass is also three female directors.
} 
groups: uniform (0\%-100\%), skewed (dominant group v.s. token group), tilted (minority v.s. majority group), and balanced group (50\%-50\%), and argue that the female interaction dynamics is very different in each group. Empirically, a tilted supervisory board sometimes outperforms a skewed supervisory board (Joecks et al., 2013; Torchia et al., 2011). The female board ratio of our gender diverse portfolios is approximately $30 \%$ or three female board members.16 ${ }^{16}$ We conjecture that the non-linear U-shape pattern will also exhibit in the relationship between idiosyncratic volatility and female board ratio. In light of the aforementioned discussion, we include an additional quadratic term Female Ratio $o_{t-1}^{2}$ in Equation (3).

\section{Investing Gender Diversity: CSR Channel Hypothesis}

In this section, we investigate one potential channel in which corporate gender diversity might lead to a lower idiosyncratic risk for stock. Some existing studies have already hinted on how female leaders might have contributed to a reduced corporate business risk. Adams and Ferreira (2009) note that female directors have better board attendance records than male directors, and they are more likely to attend and participate in corporate committees dealing with risk management. On the other hand, Sila et al. (2016) document that firm's level of risk taking affects the choice of director's gender, but not the other way round. Atkinson et al. (2003) find male- and female-managed mutual funds do not differ significantly in terms of risk taking. Indeed, it is well-known that female workforce is below men. According to World Bank statistics, the overall women employment in 2014 is slightly below $40 \%$ of the total labor force ${ }^{17}$ and even lower at corporate board level (12\%, according to our sample). Therefore, it is often argued that those women who have already reached the top of the corporate ladder are bolder (i.e. taking more risk) or tougher than average. Unfortunately, we have no means of assessing the risk appetite or risk taking behavior of the individual female directors. It is not possible to investigate here the possible link between a smaller idiosyncratic risk and the female directors' personal traits.

At the time of writing, corporate gender diversity is often analyzed with respect to

\footnotetext{
${ }^{16}$ See Table 1 .

${ }^{17}$ For women participation in labor market from 1990 to 2014, see http://data.worldbank.org/ indicator/SL. TLF. TOTL.FE.ZS
} 
corporate performance and corporate governance instead of under corporate responsibility and business ethics. In comparison, these have been many studies on CSR (Corporate Social Responsibility) and SRI (Socially Responsible Investment) that are based on sustainability and ethics. Furthermore, Godfrey (2005), among others, argues that stock market investors are willing to invest in firms with better CSR records because these firms provide "insurance like" protection: investors suffer less when CSR firms are in trouble. Empirically, Bialkowski and Starks (2016) document that flows to self-reported CSR mutual funds are less sensitive to the funds' performance than conventional funds, suggesting that SRI investors are less likely to withdraw immediately when the CSR funds just begin to perform poorly; profitability is not the sole investment objective for these SRI investors (Sparkes and Cowton, 2004). In light of these studies, we form our next hypothesis which we call the CSR Channel hypothesis:

H2: The reason that shareholders of firms included in the gender diverse portfolios are less sensitive (hence lower IdioVol) is because these firms are CSR firms.

To test hypothesis $H 2$, we first regress individual firm's female board ratio on CSR score and other control variables as follows:

$$
\text { FemaleRatio }_{i, t}=c+\beta \text { Control }_{i, t}+\gamma C S R_{i, t}+e_{i, t}
$$

where Control is a vector of firm characteristics, and $C S R$ is firm's corporate social responsibility score. All variables in Equation (4) are annual data. The control variables include the logarithmic of market capitalization, board size, ROA, leverage, sales, and dividend to control for firm characteristics. Board size is the number of directors; ROA is return on asset calculated as the firm's net profit divided by total asset; leverage is calculated as the sum of short- and long-term debts divided by total asset; sales and dividend are both scaled by total asset. These control variables have been found in previously studies to be related to board gender diversity; Martín-Ugedo and MinguezVera (2014) find positive relationship between ROA and female board ratio, while Saeed et al. (2016) find positive relationship between firm size and board gender diversity. For CSR score, we use two specific KLD ESG scores; the overall score (ALL) and the diversity score (DIV). Since the KLD diversity score also includes gender diversity, it will bias the regression result. Hence, we remove board gender diversity score from DIV and ALL, as 
mentioned in DATA section.

Next, we re-run regression (2), but use the fitted values, FemaleRatio $o_{i, t}^{*}=c+$ $\beta$ Control $_{i, t}+\gamma C S R_{i, t}$, from Equation (4) instead of the actual values:

$$
\begin{aligned}
\text { IdioVol }_{i, t}= & c+\alpha_{1} \times \beta_{i, t}^{M k t R f}+\alpha_{2} \times \beta_{i, t}^{S M B}+\alpha_{3} \times \beta_{i, t}^{H M L}+\alpha_{4} \times \beta_{i, t}^{M O M} \\
& +\alpha_{5} \times \text { FemaleRatio }{ }_{i, t-1}^{*}+e_{i, t}
\end{aligned}
$$

We also include sector and year dummies to control for sector and time effect. Since, Female Ratio $i, t$ is the portion explained by CSR in Equation (4), this two-step regression gives an indication on the degree to which the gender-risk relationship is due to our CSR channel hypothesis.

One can consider the KLD ESG scores used in this two-stage least square (TSLS) regression as an instrumental variable for female ratio. The benefits of using TSLS are twofold: to test our CSR channel hypothesis and to address the potential endogeneity issue in Equation (3), namely women directors might be more risk averse, and firms that are more risk averse might tend to hire more women. Since we cannot observe female directors personal traits and firms' risk appetite, we cannot address this endogeneity issue directly. We choose to use CSR as a risk attitude independent instrumental variable for two reasons: (1) CSR is related to female ratio (which we will provide direct evidence in the next section), and (2) a valid instrumental variable should not be a surrogate for firm's (idiosyncratic) risk; there is no theory or empirical evidence to suggest firm's CSR score is related to firm's risk. Firms have clear motivation to improve CSR performance (Jamali and Mirshak, 2007) and maximize stakeholder's benefit by maintaining a good local community relationship, seeking better employees, and improving customer loyalty (Du et al., 2010). Hence, CSR score satisfied both criteria. Thus, it is a valid instrumental variable for female (board) ratio in Equation (5).

\section{Does Board Gender Diversity Leads to Improved CSR?}

Thus far, we conjecture that the lower idiosyncratic risk for firms with more female directors is linked to firm's better CSR score. However, it is not clear if such a connection is coincidental or there is a fundamental causal relationship. This is the subject for 
investigation in this section.

Corporate reputation is one of the central issues in corporate governance and management because of it's huge impact on firm's value. Until recently, the main focus of corporate reputation research has been on brand, with the most prominent textbook example being the branding strategy of Coca Cola. Some studies link reputation to user experience (Bontis et al., 2007) and media visibility (Fombrun and Shanley, 1990). More recent studies, however, note that brand value is also driven by firm's CSR performance (Donker et al., 2008; Gardberg and Fombrun, 2006; Vanhamme and Grobben, 2009). They argue that CSR, acting as a safety net, can reduce firms' reputation damage. The natural question that follows is if board gender diversity is related to firm's CSR performance. Bear et al. (2010) study 51 healthcare firms from the Fortune's 2009 survey and find board gender diversity can indeed improve the firm's technology strength (KLD ESG: PRO+GOV+EMP) and institutional strength (KLD ESG: COM+DIV). Extending these previous studies, our paper provides more comprehensive analyses by testing if more female board members can increase firm's overall CSR performance, as well as specific CSR subcategories. Hence, our third hypothesis is:

H3: Board gender diversity improves CSR overall performance, as well as each of the seven CSR subcategories.

Here we narrow our female ratio to female board ratio, FemaleBdRatio, i.e. the ratio of the number of female directors to board size. To test hypothesis $H 3$, we perform a set of first-difference regressions as follows:

$$
\begin{aligned}
& \Delta C S R_{i, t}=c+\beta_{1} \Delta \text { Control }_{i, t}+\gamma_{1} \Delta \text { FemaleBdRatio }_{i, t-1}+e_{i, t}^{C S R} \\
& \Delta \text { FemaleBdRatio }_{i, t+1}=c+\beta_{2} \Delta \text { Control }_{i, t}+\gamma_{2} \Delta C S R_{i, t}+e_{i, t}^{F B R}
\end{aligned}
$$

where $\Delta$ is the yearly difference; Control is a vector of control variables, including the logarithmic of market capitalization, board size, ROA, leverage, sales, and dividend; $\triangle$ FemaleBdRatio ${ }_{i, t-1}$ is the change in female board ratio in the previous year; and $C S R$ is the KLD ESG score. We use the overall score (ALL), and seven subcategory scores viz. Environment (ENV), Community (COM), Human Rights (HUM), Employee (EMP), Diversity (DIV), Product (PRO), and Governance (GOV). In both Equations (6) and (7), 
we include sector and year dummies to control for sector and time fixed effects.

The structure of the set of regressions is designed to test the reverse causality between board gender diversity and CSR. Sila et al. (2016) argue that gender diversity does not affect board's risk-taking, but it is the firm's level of risk-taking that affects the choice of director's gender. Following the same argument, it is plausible that a firm that has a good CSR record will go on to appoint more female directors. We use this set of regressions to test both explanations. Under hypothesis $H 3$, we expect to have significant $\gamma_{1}$ and insignificant $\gamma_{2}$ coefficients. If the reverse causality is true then $\gamma_{2}$ will also be statistically significant.

So far, we have been using the net KLD ESG scores, i.e. the difference between the corresponding scores for strengths and concerns (see MSCI ESG Research, 2015). Some studies find KLD ESG strength and concern scores produce very different impact, and recommend that "researchers needed to separately utilize the strength's and concern's ratings" (Bear et al., 2010). Mattingly and Berman (2006) also suggest that the KLD ESG strength and concern ratings can be classified into four types: institutional strength, technical strength, institutional weakness, and technical weakness. For example, diversity strength is linked to institutional strength (i.e. the stakeholders normative expectation), and diversity concern is linked to technical weakness (i.e. the capability of firm resource exchange) ${ }^{18}$ Following these two studies, we test if female board members affect strengths and concerns differently. Specifically, we hypothesize that a gender diverse board improves strength and reduces concern:

H3a: Board gender diversity improves overall CSR strength and the seven CSR subcategories. and

H3b: Board gender diversity reduces overall CSR concern and its seven CSR subcategories.

We note that the calculation of KLD ESG scores on strength or concern are categorical and non-negative. Hence, a Poisson regression is used instead of the OLS regression for testing $H 3 a$ and $H 3 b$. The Poisson regression is also ideal for capturing any non-linear impact of female board ratio on KLD strength (or concern). The regression specification

\footnotetext{
${ }^{18}$ See Table 3 in Mattingly and Berman (2006) for detailed explanations of the classification and components.
} 
is expressed as follows:

$$
\operatorname{Prob}\left\{Y_{i, t}=y_{i, t} \mid X\right\}=\frac{e^{-\lambda_{i, t}} \lambda_{i, t}^{y_{i, t}}}{y_{i, t} !}
$$

where $y_{i, t}$ is the KLD ESG strength (or concern) with the expected rate of occurrence $\lambda$, a latent variable which in turns is determined by:

$$
\log \lambda_{i, t}=c+\beta_{1} y_{i, t-1}+\beta_{2} \Delta \text { Control }_{i, t}+\gamma \Delta \text { FemaleBdRatio }_{i, t-1}+e_{i, t},
$$

where $y_{i, t-1}$ is the firm's strength (or concern) in the previous year; $\Delta$ is the yearly difference; Control is a vector of control variables, which include the logarithmic of market capitalization, board size, ROA, leverage, sales, and dividend; $\Delta$ FemaleBdRatio $_{i, t-1}$ is the change in female board ratio in the previous year.

\section{RESULTS}

\section{Backtesting Portfolio Performance}

Table 4 reports the means, in basis point, and the standard deviations of monthly portfolio excess return and monthly Carhart risk factors. The market risk premium (Rm-Rf) and size premium (SMB) are fairly stable in the two sub-periods. The growth premium (HML) and the momentum factor (MOM) are highly positive in the first sub-period and highly negative in the second sub-period possibly due to the subprime crisis. All portfolios have positive excess returns over the full and two sub-sample periods. All five gender diverse portfolios have similar excess return, with WIL having the highest excess return (66.66 bp) and MSParity having the lowest (59.08 bp). HE produces the highest excess return (78.94 bp), and highest standard deviation (517.39 bp) compared with the five gender diverse portfolios.

Portfolios performance is very different in the two sub-sample periods in Table 4. All gender diverse portfolios perform better in the second sub-sample period (i.e. with a much higher excess returns). The reverse is true for HE which was badly affected by the 2008 subprime crisis. 
Table 5 reports the results of excess return regression using the Carhart four-factor model. For the full sample period, all portfolios have positive but statistically insignificant alphas. When separated into sub-periods, HE is the only portfolio to have a negative alpha in the second sub-period, but none of the alphas is statistically different from zero for all portfolios. The magnitudes and signs of the factor loading suggest that all five gender diverse portfolios are defensive (with market beta less than 1), larger size firms (with negative loading on SMB), and value stocks (with positive loading on HML). The reverse is true for $\mathrm{HE}$.

Our backtest results above show that all portfolios, gender diverse or not, do not produce significant alphas; hence, hypothesis $H 1$ is rejected. Next, we test if there exists different return and risk characteristics between portfolios ( $H 1 a$ and $H 1 b)$, and the results are reported in Table 6. Panel A of Table 6] shows there is no statistically significant difference in risk-adjusted excess return among all portfolios. The results here support the argument, e.g. Carter et al. (2010), that gender diversity does not have immediate impact on firm performance. Our finding of zero alpha is consistent with the theory of an efficient stock market.

Table 6, Panel B shows the risk comparison between portfolios. The first row of Panel B shows that HE's idiosyncratic risk is higher than all five gender diverse portfolios. Specifically, the idiosyncratic volatility of HE is 1.43 (HE vs. WIL) to 2.48 (HE vs. US2020) times higher than those of the gender diverse portfolios. All the variance test ratio is significance at the $1 \%$ level, except the HE-WIL pair where it is significant at the $5 \%$ level. The results in Table 6 indicate that the stock market's reaction to gender diversity is reflected in reduction in risk, instead of a higher return. This new finding contributes to corporate gender diversity research and extends the findings in Adams and Ferreira (2009) and Chapple and Humphrey (2014).

Among the gender diverse portfolios, SHE, WOB, MSParity, and WIL, there is no significant difference in return and risk. Only US2020 is less risky than the other four gender diverse portfolios at the $5 \%$ level. 


\section{Firm Level Analyses}

Table 7 reports the results for Fama-MacBeth regression of board gender diversity on firm's idiosyncratic volatility. The first two columns use female ratio which includes both board and senior management; the last two columns use board female ratio. All $\beta^{S M B}$ is significant at the $1 \%$ level, suggesting that small firms are likely to have higher idiosyncratic volatility. Consistent with our findings from the portfolio analyses in the previous section, Female Ratio ${ }_{t-1}$ has a negative impact on idiosyncratic risk; the factor loading is -0.101 and -0.120 , respectively, for female ratio and female board ratio, and both are significant at the $1 \%$ level. From the firm's perspective, a firm is an undiversified single-stock portfolio. Therefore, it is important for firm to reduce its idiosyncratic risk.

Furthermore, Table 7 shows positive loadings on the quadratic term, Female Ratio ${ }_{t-1}^{2}$ (0.757 and 0.560, respectively, for female ratio and female board ratio both significant at the $1 \%$ level), suggesting a non-linear relationship between firm's idiosyncratic risk and board gender diversity. Together with the negative loadings on FemaleRatio Fe $_{-1}$, the results suggest the relationship between female leadership and idiosyncratic risk to be of a U-shape pattern: gender diversity can reduce firm risk; but it has an adverse impact on firm's idiosyncratic risk if the female ratio is too high.

Next, we take the loadings on FemaleRatio Fe $_{-1}$ and FemaleRatio ${ }_{t-1}^{2}$ from the female board ratio model (last column in Table 7) to calculate the impact of board gender diversity on $\mathrm{IdioVol}_{t}$. For example, everything else equal, a female board ratio of $5 \%$ will reduce idiosyncratic risk by 0.013 (i.e. $-0.292 \times 5 \%+0.560 \times 5 \%^{2}$ ). Similarly, a female board ratio of $25 \%$ will reduce idiosyncratic risk by 0.038 (i.e. $-0.292 \times 25 \%+$ $\left.0.560 \times 25 \%^{2}\right)$. However, the firm's idiosyncratic risk starts to increase if the female board ratio is larger than $30 \%$. For example, a firm with $45 \%$ of female board ratio reduces idiosyncratic risk by 0.018 (i.e. $-0.292 \times 45 \%+0.560 \times 45 \%{ }^{2}$ ) which is not as much as when the female board ratio is $25 \%$. Figure $3 \mathrm{i}$ plots this relationship and shows clearly the nonlinear relationship between idiosyncratic risk and female board ratio with $30 \%$ being the optimal female board ratio. Similarly, Figure 3ii presents the impact of the number of female board members on $\mathrm{IdioVol}_{t}$ given the average board size of 10. Figure 3ii shows that only three female directors has the greatest reduction in idiosyncratic risk. ${ }^{19}$

\footnotetext{
${ }^{19}$ The calculation for only 3 is $-0.037=-0.292 \times \frac{3}{10}+0.560 \times\left(\frac{3}{10}\right)^{2}$.
} 
consistent with the critical mass literature, e.g. $30 \%$ female board ratio in Joecks et al. (2013) and three female board members in Torchia et al. (2011).

\section{CSR Channel Results}

Table 8 reports the results for our CSR channel hypothesis. We find that the loadings for FemaleRatio*, using the KLD ESG scores as instrumental variables, are all negative. With female ratio, the loadings are -0.731 and -0.448 , respectively, for ALL and DIV. Using female board ratio, the loadings are -0.742 and -0.482 , respectively, for ALL and DIV. All four coefficients are significant at the $1 \%$ level. The statistical significance and the conclusion do not change when the control variables are removed from Equation (4). These results provide strong evidence that stock market investors in gender-diverse firm are less price sensitive (and hence their shares have less idiosyncratic risk) as such firms provide CSR insurance-like downside protection.

\section{Board Gender Diversity and CSR}

Table 9 reports the results for first-difference regression in Equation (6). Supporting the hypothesis $H 3, \gamma_{1}(1.071)$ for FemaleBdRatio is significant at the $1 \%$ level suggesting that a higher female board ratio is followed by improved firm's overall CSR performance. Interestingly, when we perform the same analysis on KLD ESG subcategory scores, we find that $\gamma_{1}$ is significant only for DIV and GOV (0.283 for DIV at the $10 \%$ level and 0.397 for GOV at the $1 \%$ level). These findings suggest that female directors have a greater impact on workforce gender diversity and on corporate governance 20 Our findings for CSR improvement in corporate governance is consistent with the findings in Adams and Ferreira (2009), where the authors note that female board members are more likely to join corporate governance panels. Table 10 reports the other set of the first-difference regression. The $\gamma_{2}$ loadings for ALL, DIV, and GOV ESG scores are statistically insignificant suggesting that there is no reverse causality; firms with better CSR scores do not go on to appoint more female directors. ${ }^{21}$

\footnotetext{
${ }^{20}$ We have removed all the board gender diversity scores from all ESG scores to avoid spurious results.

${ }^{21}$ We find some weak significance that the loadings on environmental and communication affect the female board ratio.
} 
To detect if there exists a non-linear impact from female board members on KLD ESG scores, we repeat Equation (6) and include additional quadratic term of female board ratio (FemaleBdRatio $o_{t-1}^{2}$ ). The results (not reported here) do not support any nonlinear relationship. The loading on FemaleBdRatio ${ }^{2}$ is -3.229 [t-stat: 1.65] for ALL, -0.358 [t-stat: 0.47] for DIV, and -0.406 [t-stat: 0.56] for GOV.

Table 11 reports the Poisson regression results separately for firm's CSR strength and concern ratings for each sub-category and their aggregate. At the aggregate level (ALL), the loading on strength is insignificant, while the loading on concern is -0.340 , significant at the $1 \%$ level. This means that one standard deviation increase in female board ratio leads to $3.34 \%\left(\Delta \lambda=e^{0}-e^{-0.340 \times 0.10}\right)$ reduction in concern at the aggregate level. This finding is consistent with Mattingly and Berman (2006) who find the female board members' influence on firm's CSR performance is partial.

Next, we look at the sub-category ratings, the impact on concern at the aggregate level is mainly driven by DIV and GOV (-1.723 for DIV, significant at the $1 \%$ level; -0.513 for GOV, significant at the $10 \%$ level). This means that one standard deviation increase in female board ratio leads to $15.82 \%\left(\Delta \lambda=e^{0}-e^{-1.723 \times 0.10}\right)$ reduction in the DIV concern rating and $5.00 \%\left(\Delta \lambda=e^{0}-e^{-0.513 \times 0.10}\right)$ reduction in the GOV concern rating. The impact is much stronger on gender diversity than on corporate governance. As for category strength ratings, we find some significant impact on community and employee relationship categories (0.879 for COM, significant at the $1 \%$ level; 0.519 for EMP, significant at $10 \%$ level).

As a robustness test, we run first-difference regression for strength and concern, controlling for sector and year fixed effects. We find the results (not reported here) are largely the same, except that the loading for COM strength becomes insignificant. The loadings for ALL, COM, and EMP strength ratings are 0.360 [t-stat: 1.20], 0.043 [t-stat: 0.56], and 0.353 [t-stat: 2.21]. The loadings for ALL, DIV, and GOV concern ratings are -0.711 [t-stat: 2.93], -0.446 [t-stat: 4.57], and -0.324 [t-stat: 2.85]. Our findings is slightly different from Bear et al. (2010), where the authors argue that board diversity improves both technology strength $(\mathrm{PRO}+\mathrm{GOV}+\mathrm{EMP})$ and institutional strength $(\mathrm{COM}+\mathrm{DIV})$. However, when we include a larger sample size and a longer sample period than Bear et al. (2010), we find strength improvements only for EMP and DIV. 
Interestingly, Kumar et al. (2016) argues that “... strengths in CSP [corporate social performance] related to primary stakeholder domains are associated with superior corporate performance. ... weaknesses [concerns] in CSP, the results suggest that if a firm performs poorly in meeting the expectations of one or more stakeholders it is penalized in the form of poor performance." Our findings here suggest female directors help to prevent concerns and corporate poor performance, instead of improving strengths leading to superior corporate performance. This seems to be consistent with our portfolio analyses whereby gender diverse portfolios present themselves as being less risky, instead of generating superior return.

\section{DISCUSSION AND CONCLUSION}

\section{Contribution}

Our research contributes to a better understanding of the rationale for investing in firms that embrace gender diversity. In particular, we provide comprehensive analyses of the risk-return profiles of five market traded gender diverse equity portfolios. Our findings are consistent with several previous studies where no abnormal return was found (Austrian market: Chapple and Humphrey; UK market: Gregory-Smith et al.). Furthermore, we find strong evidence that gender diverse portfolios have less residual risks. We argue that this is because investors of (board) gender diverse firms are less price sensitive. We link this finding to firm's better CSR performance and insurance-like downside protection.

Our research on gender diverse firms is important for the recent trend of socially responsible investors, who incorporate firm's environmental, social, and governance aspects into their investment criteria. Ioannou and Serafeim (2015) note that, nowadays, firms with high CSR score are more likely to receive positive recommendation from experience or large brokerage house analysts; in the early 1990's, analysts used to have pessimistic viewpoints for these firms. Given the strong association between female directors and reduced concerns in corporate diversity and corporate governance, we argue that these gender diverse equity portfolios form an important new asset class widening the investment choice for the increasingly important SRI (Socially Responsible Investment) community. 


\section{Conclusion}

Using the top 1,000 US stocks from 2002 to 2015 as the tradable asset universe, we replicate and backtest the portfolio performance of five market traded gender diverse stock portfolios, viz. SSGA's SHE, Barclay's WIL (Women In Leadership), MSCI's WOB Index (Women on Board), Morgan Stanley's Parity Portfolio (MSParity), and US2020 (Sonnabend, 2015). Using the Carhart four-factor model, we find that, in comparison to the male dominated counterpart, gender diverse portfolios perform equally well, on a risk-adjusted basis, and have less idiosyncratic risks. Our research findings unanimously indicates a smaller investment risk in these gender diverse portfolios. Additional results from panel regressions suggest that these findings are also robust at the firm specific level.

To understand further the gender-CSR-risk relationship, we use CSR as an instrumental variable for board gender diversity, and find a statistically significant association between high CSR performance and reduced idiosyncratic risk, suggesting that gender effect on stock riskiness is through the CSR channel.

Further empirical analyses confirm that, despite smaller presence than men, female leadership helps to improve corporate social responsibility performance. We have ruled out the reverse causality, i.e. there is no evidence to support the hypothesis that firms with good CSR performance will go on to hire more women executives. We have carefully adjusted the KLD diversity score for board diversity to avoid any spurious results.

\section{Limitation and Future Research}

Due to the restriction on stock liquidity and data quality, market-traded gender based portfolios tend to be composed of stocks from large market capitalization firms. The exchange traded fund, SHE, marketed by State Street Global Advisors has the largest top 1,000 US market capitalization firms as the investment universe, which we adopt as our sample universe. Therefore, our results are confined to large US firms and our findings are strictly related to investment and capital market asset pricing only. Gender diverse portfolios may have different characteristics if the stock universe is from a different region or country and includes small firm stocks. Such gender diversity research in future could also consider a global universe since there are mutual funds that cover global equity and 
gender diversity (e.g. Pax Ellevate Golbal Women's Index. Ticker: PXWIX); this area of research has not yet been explored.

Another limitation of our study is the choice of MSCI KLD Corporate CSR (Corporate Social Responsibility) indicators. There are other agencies (e.g. Sustainalytics, Bloomberg, Asset4, FTSE4good, RepRisk etc) that provide similar CSR (or ESG; Environment, Social and Governance) scores. The CSR performance measures and assessment criteria of different agencies are different from one another. While MSCI KLD indicators are well established and widely used especially among the academic research community, our findings here may change had we used a different set of CSR performance measures from another agency.

Finally, the TSLS regression is normally used for addressing endogeneity. Here, we use CSR as an instrumental variable for female board ratio for testing the connection between female board ratio and idiosyncratic volatility. Here, we extend further and argue that CSR is a channel to which female directors' actions reduce firms' idiosyncratic risk. 


\section{References}

Abdullah, S. N., K. N. I. K. Ismail, and L. Nachum (2016). Does having women on boards create value? the impact of societal perceptions and corporate governance in emerging markets. Strategic Management Journal 37(3), 466-476.

Adams, R. B., J. de Haan, S. Terjesen, and H. van Ees (2015). Editorial: Board diversity: Moving the field forward. Corporate Governance: An International Review 23(1), 7782.

Adams, R. B. and D. Ferreira (2009). Women in the boardroom and their impact on governance and performance. Journal of Financial Economics 94(2), 291-309.

Ang, A., R. Hodrick, Y. Xing, and X. Zhang (2006). The cross-section of volatility and expected returns. The Journal of Finance 61(1), 259-299.

Ang, A., R. Hodrick, Y. Xing, and X. Zhang (2009). High idiosyncratic volatility and low returns: International and further US evidence. Journal of Financial Economics 91(1), $1-23$.

Atkinson, S. M., S. B. Baird, and M. B. Frye (2003). Do female mutual fund managers manage differently? Journal of Financial Research 26(1), 1-18.

Bear, S., N. Rahman, and C. Post (2010). The impact of board diversity and gender composition on corporate social responsibility and firm reputation. Journal of Business Ethics 97(2), 207-221.

Bertrand, M., S. Black, S. Jensen, and A. Lleras-Muney (2014). Breaking the glass ceiling? The effect of board quotas on female labor market outcomes in Norway. Working Paper.

Bialkowski, J. and L. Starks (2016). SRI funds: Investor demand, exogenous shocks and ESG profiles. Working Paper.

Bohren, O. and R. O. Strom (2010). Governance and politics: Regulating independence and diversity in the board room. Journal of Business Finance $\&$ Accounting 37(9-10), 1281-1308.

Bontis, N., L. Booker, and A. Serenko (2007). The mediating effect of organizational reputation on customer loyalty and service recommendation in the banking industry. Management Decision 45(9), 1426-1445.

Brennan, M., S.-W. Huh, and A. Subrahmanyam (2013). An analysis of the Amihud illiquidity premium. Review of Asset Pricing Studies 3(1), 133-176.

Carter, D. A., F. D'Souza, B. J. Simkins, and W. G. Simpson (2010). The gender and ethnic diversity of US boards and board committees and firm financial performance. Corporate Governance: An International Review 18(5), 396-414.

Chapple, L. and J. E. Humphrey (2014). Does board gender diversity have a financial impact? Evidence using stock portfolio performance. Journal of Business Ethics 122(4), 709-723.

Choi, J. and H. Wang (2009). Stakeholder relations and the persistence of corporate financial performance. Strategic Management Journal 30(8), 895-907. 
Dezsö, C. L. and D. G. Ross (2012). Does female representation in top management improve firm performance? A panel data investigation. Strategic Management Journal 33(9), 1072-1089.

Donker, H., D. Poff, and S. Zahir (2008). Corporate values, codes of ethics, and firm performance: A look at the Canadian context. Journal of Business Ethics 82(3), $527-537$.

Du, S., C. B. Bhattacharya, and S. Sen (2010). Maximizing business returns to corporate social responsibility (CSR): The role of CSR communication. International Journal of Management Reviews 12(1), 8-19.

Fombrun, C. and M. Shanley (1990). What's in a name? Reputation building and corporate strategy. Academy of Management Journal 33(2), 233-258.

Garcia-Meca, E., I.-M. Garcia-Sanchez, and J. Martinez-Ferrero (2015). Board diversity and its effects on bank performance: An international analysis. Journal of Banking $\&$ Finance 53, 202-214.

Gardberg, N. and C. Fombrun (2006). Corporate citizenship: Creating intangible assets across institutional environments. Academy of management Review 31 (2), 329-346.

Godfrey, P. (2005). The relationship between corporate philanthropy and shareholder wealth: A risk management perspective. Academy of Management Review 30(4), 777798.

Godfrey, P., C. Merrill, and J. Hansen (2009). The relationship between corporate social responsibility and shareholder value: An empirical test of the risk management hypothesis. Strategic Management Journal 30(4), 425-445.

Gregory-Smith, I., B. G. Main, and C. A. O'Reilly (2014). Appointments, pay and performance in UK boardrooms by gender. The Economic Journal 124(574).

Hillman, A. and G. Keim (2001). Shareholder value, stakeholder management, and social issues: What's the bottom line? Strategic Management Journal, 125-139.

Ioannou, I. and G. Serafeim (2015). The impact of corporate social responsibility on investment recommendations: Analysts' perceptions and shifting institutional logics. Strategic Management Journal 36(7), 1053-1081.

Jamali, D. and R. Mirshak (2007). Corporate social responsibility (CSR): Theory and practice in a developing country context. Journal of Business Ethics 72(3), 243-262.

Joecks, J., K. Pull, and K. Vetter (2013). Gender diversity in the boardroom and firm performance: What exactly constitutes a "critical mass?". Journal of Business Ethics 118(1), 61-72.

Kang, E., D. K. Ding, and C. Charoenwong (2010). Investor reaction to women directors. Journal of Business Research 63(8), 888-894.

Kanter, R. M. (1977). Some effects of proportions on group life: Skewed sex ratios and responses to token women. American Journal of Sociology 82(5), 965-990.

Koh, P.-S., C. Qian, and H. Wang (2014). Firm litigation risk and the insurance value of corporate social performance. Strategic Management Journal 35(10), 1464-1482. 
Konrad, A. M., V. Kramer, and S. Erkut (2008). Critical mass: The impact of three or more women on corporate boards. Organizational Dynamics 37(2), 145-164.

Kumar, K., G. Boesso, and G. Michelon (2016). How do strengths and weaknesses in corporate social performance across different stakeholder domains affect company performance? Business Strategy and the Environment 25(4), 277-292.

Lyngsie, J. and N. J. Foss (2017). The more, the merrier? women in top-management teams and entrepreneurship in established firms. Strategic Management Journal 38(3), $487-505$.

Marquis, C. and M. Lee (2013). Who is governing whom? executives, governance, and the structure of generosity in large US firms. Strategic Management Journal 34(4), $483-497$.

Martín-Ugedo, J. F. and A. Minguez-Vera (2014). Firm performance and women on the board: Evidence from Spanish small and medium-sized enterprises. Feminist Economics 20(3), 136-162.

Mattingly, J. and S. Berman (2006). Measurement of corporate social action discovering taxonomy in the Kinder Lydenburg Domini ratings data. Business 63 Society 45(1), 20-46.

MSCI ESG Research (2015, June). MSCI ESG KLD Stats: 1991-2014 data sets. Technical report, MSCI.

Saeed, A., Y. Belghitar, and A. Yousaf (2016). Firm-level determinants of gender diversity in the boardrooms: Evidence from some emerging markets. International Business Review 25(5), 1076-1088.

Sila, V., A. Gonzalez, and J. Hagendorff (2016). Women on board: Does boardroom gender diversity affect firm risk? Journal of Corporate Finance 36, 26-53.

Sonnabend, S. (2015). Gender diversity in the corporate boardroom: Creating a tipping point for change. Journal of Management Inquiry 24 (2), 212-213.

Sparkes, R. and C. J. Cowton (2004). The maturing of socially responsible investment: A review of the developing link with corporate social responsibility. Journal of Business Ethics 52(1), 45-57.

Terjesen, S., R. V. Aguilera, and R. Lorenz (2015). Legislating a woman's seat on the board: Institutional factors driving gender quotas for boards of directors. Journal of Business Ethics 128(2), 233-251.

Torchia, M., A. Calabro, and M. Huse (2011). Women directors on corporate boards from tokenism to critical mass. Journal of Business Ethics 102, 299-317.

Vanhamme, J. and B. Grobben (2009). "Too good to be true!". The effectiveness of CSR history in countering negative publicity. Journal of Business Ethics 85, 273-283.

Watson, P. (1995). Equality of treatment: A variable concept. Industrial Law Journal 24 , 33.

World Bank Group (2015). Women, Business and the Law 2016: Getting to Equal. World Bank Group. 
Table 1: Corporate Board Descriptive Statistics for Gender Portfolios This table reports the average board size and average female board ratio for various gender diverse portfolios, viz. SHE, WOB, US2020, MSParity, $W I L$, and HE. SHE mimics SSGA's ETF with ticker SHE, HE is created here to contrast $S H E$. WOB mimics MSCI Women On Board Index, US2020 is a campaign led by Sonnabend (2015), MSParity mimics Morgan Stanley Parity Portfolio and WIL mimics Barclays Women In Leadership ETN. Standard deviations are in parenthesis. $\mathrm{N}$ is the total number of firm years.

\begin{tabular}{lcccc}
\hline & $\begin{array}{c}\text { Board } \\
\text { Size }\end{array}$ & $\begin{array}{c}\text { Female } \\
\text { Board Size }\end{array}$ & $\begin{array}{c}\text { Female } \\
\text { Board Ratio }\end{array}$ & $\mathrm{N}$ \\
\hline Full Sample & 9.47 & 1.19 & 0.12 & 20,921 \\
& $(2.67)$ & $(1.05)$ & $(0.10)$ & \\
SHE & 10.34 & 2.82 & 0.27 & 1,131 \\
& $(2.31)$ & $(1.15)$ & $(0.10)$ & \\
WOB & 11.84 & 3.29 & 0.28 & 1,880 \\
& $(2.40)$ & $(0.74)$ & $(0.07)$ & \\
US2020 & 10.32 & 2.67 & 0.26 & 3,409 \\
\multirow{2}{*}{ MSParity } & $(2.15)$ & $(0.87$ & $(0.06)$ & \\
& 12.02 & 3.38 & 0.29 & 1,760 \\
WIL & $(2.43)$ & $(0.68)$ & $(0.07)$ & \\
& 10.35 & 3.00 & 0.29 & 1,931 \\
HE & $(2.33)$ & $(0.98)$ & $(0.07)$ & \\
& 8.82 & 0.24 & 0.02 & 3,473 \\
& $(2.58)$ & $(0.45)$ & $(0.04)$ & \\
\hline
\end{tabular}


Table 2: Corporate Social Responsibility Mean Scores

This table reports the mean and standard deviations (Std) of the CSR scores for all firms in our tradable US stock universe over the full sample period of 2002 to 2015 and two sub-periods. There are 1,951 firms in total. $\mathrm{N}$ is the total number of firm years. "Overall Score" is Strength minus Concern. N is the total number of firm years.

\begin{tabular}{|c|c|c|c|c|c|c|}
\hline & \multicolumn{2}{|c|}{$2002-2015$} & \multicolumn{2}{|c|}{$2002-2007$} & \multicolumn{2}{|c|}{$2008-2015$} \\
\hline & Mean & Std & Mean & Std & Mean & Std \\
\hline \multicolumn{7}{|c|}{ Panel A: Strength } \\
\hline Combined & 2.02 & 2.83 & 1.61 & 2.25 & 2.41 & 3.24 \\
\hline Environment & 0.35 & 0.82 & 0.15 & 0.48 & 0.55 & 1.00 \\
\hline Community & 0.23 & 0.59 & 0.21 & 0.58 & 0.26 & 0.60 \\
\hline Human Rights & 0.02 & 0.17 & 0.01 & 0.08 & 0.04 & 0.22 \\
\hline Employee & 0.50 & 0.98 & 0.35 & 0.67 & 0.65 & 1.19 \\
\hline Diversity & 0.76 & 1.20 & 0.80 & 1.20 & 0.71 & 1.20 \\
\hline Product & 0.11 & 0.34 & 0.07 & 0.28 & 0.15 & 0.38 \\
\hline Governance & 0.14 & 0.38 & 0.13 & 0.35 & 0.15 & 0.40 \\
\hline \multicolumn{7}{|c|}{ Panel B: Concern } \\
\hline Combined & 2.12 & 2.16 & 2.22 & 2.17 & 2.04 & 2.16 \\
\hline Environment & 0.30 & 0.76 & 0.31 & 0.79 & 0.29 & 0.74 \\
\hline Community & 0.11 & 0.33 & 0.12 & 0.36 & 0.09 & 0.31 \\
\hline Human Rights & 0.07 & 0.28 & 0.09 & 0.31 & 0.05 & 0.24 \\
\hline Employee & 0.45 & 0.71 & 0.50 & 0.70 & 0.41 & 0.71 \\
\hline Diversity & 0.44 & 0.61 & 0.32 & 0.49 & 0.56 & 0.68 \\
\hline Product & 0.33 & 0.68 & 0.35 & 0.69 & 0.31 & 0.66 \\
\hline Governance & 0.52 & 0.64 & 0.53 & 0.64 & 0.50 & 0.65 \\
\hline \multicolumn{7}{|c|}{ Panel C: Overall Score } \\
\hline Combined & -0.11 & 2.84 & -0.50 & 2.42 & 0.38 & 3.17 \\
\hline Environment & 0.05 & 0.94 & -0.16 & 0.77 & 0.26 & 1.04 \\
\hline Community & 0.13 & 0.62 & 0.09 & 0.62 & 0.17 & 0.61 \\
\hline Human Rights & -0.05 & 0.30 & -0.08 & 0.31 & -0.01 & 0.30 \\
\hline Employee & 0.05 & 1.16 & -0.14 & 0.92 & 0.24 & 1.33 \\
\hline Diversity & 0.30 & 1.21 & 0.37 & 1.19 & 0.24 & 1.23 \\
\hline Product & -0.22 & 0.72 & -0.27 & 0.72 & -0.17 & 0.71 \\
\hline Governance & -0.38 & 0.74 & -0.41 & 0.73 & -0.35 & 0.76 \\
\hline $\mathrm{N}$ & 14,335 & & 7,023 & & 7,312 & \\
\hline
\end{tabular}


Table 3: Corporate Social Responsibility Sector Average

This table reports the mean and standard deviations (Std) of the KLD ALL scores by sectors in our tradable US stock universe over the full sample period of 2002 to 2015 . $\mathrm{N}$ is the total number of firm years.

\begin{tabular}{lccr}
\hline & Mean & Std & $\mathrm{N}$ \\
\hline Consumer Discretionary & -0.30 & 2.68 & 2,328 \\
Consumer Staples & 0.39 & 4.29 & 686 \\
Energy & -1.34 & 2.64 & 1,068 \\
Financials & 0.13 & 2.30 & 2,882 \\
Health Care & 0.03 & 2.50 & 1,617 \\
Industrials & -0.46 & 2.53 & 1,796 \\
Information Technology & 0.76 & 3.08 & 2,233 \\
Materials & -0.81 & 3.07 & 912 \\
Telecommunication Services & 0.09 & 2.08 & 152 \\
Utilities & -0.35 & 3.26 & 661 \\
\hline
\end{tabular}


Table 4: Average Monthly Returns for Carhart Factors and Gender Portfolios

This table reports the mean and standard deviation (Std) of monthly returns in basis points on Carhart four factors and the various gender diverse stock portfolios over the sample period of 2002 to 2015 and two sub-periods. Portfolio returns are compiled using monthly stock returns, $R m-R f$ is the market risk premium, $S M L$ is small-minus-large, $H M L$ is high-minus-low, and $M O M$ is momentum. SHE mimics SSGA's ETF with ticker SHE, $H E$ is created here to contrast $S H E, W O B$ mimics MSCI Women On Board Index, US2020 is a campaign led by Sonnabend (2015), MS Parity mimics Morgan Stanley Parity Portfolio and WIL mimics Barclays Women In Leadership ETN. $\mathrm{N}$ is the number of monthly observations.

\begin{tabular}{|c|c|c|c|c|c|c|}
\hline & \multicolumn{2}{|c|}{$2002-2015$} & \multicolumn{2}{|c|}{$2002-2007$} & \multicolumn{2}{|c|}{$2008-2015$} \\
\hline & Mean & Std & Mean & Std & Mean & Std \\
\hline \multicolumn{7}{|c|}{ Panel A: Carhart Factors } \\
\hline Rm-Rf & 64.39 & 429.76 & 64.50 & 336.58 & 64.31 & 485.28 \\
\hline SMB & 17.88 & 232.34 & 18.39 & 234.44 & 17.53 & 232.11 \\
\hline HML & -0.63 & 242.94 & 19.38 & 176.71 & -14.39 & 279.62 \\
\hline MOM & 5.60 & 488.81 & 19.89 & 400.39 & -4.22 & 543.14 \\
\hline \multicolumn{7}{|c|}{ Panel B: Gender-based Portfolios } \\
\hline $\mathrm{SHE}$ & 60.47 & 424.84 & 58.41 & 327.75 & 68.40 & 480.34 \\
\hline WOB & 59.92 & 407.54 & 50.63 & 305.64 & 70.06 & 467.33 \\
\hline US2020 & 66.31 & 414.81 & 57.76 & 318.48 & 76.67 & 471.75 \\
\hline MSParity & 59.08 & 404.29 & 49.74 & 298.53 & 69.08 & 465.80 \\
\hline WIL & 66.66 & 438.04 & 53.24 & 335.40 & 81.28 & 497.81 \\
\hline $\mathrm{HE}$ & 78.94 & 517.39 & 99.21 & 396.25 & 73.83 & 584.70 \\
\hline $\mathrm{N}$ & 162 & & 66 & & 96 & \\
\hline
\end{tabular}


Table 5: Excess Return Factor Regression

This table reports the regression of the gender diverse portfolio monthly excess returns against Carhart four factors. The sample period is from 2002 to 2015. $R m-R f$ is the market risk premium, $S M B$ is small-minus-big, $H M L$ is highminus-low, and MOM is momentum. SHE mimics SSGA's ETF with ticker SHE, $H E$ is created here to contrast $S H E, W O B$ mimics MSCI Women On Board Index, US2020 is a campaign led by Sonnabend (2015), MSParity mimics Morgan Stanley Parity Portfolio and WIL mimics Barclays Women In Leadership ETN. The corresponding $t$-statistics are reported in [ ].

\begin{tabular}{|c|c|c|c|c|c|c|}
\hline & SHE & WOB & US2020 & MSParity & WIL & $\mathrm{HE}$ \\
\hline \multicolumn{7}{|c|}{ Panel A: $2002-2015(\mathrm{~N}=162)$} \\
\hline \multirow[t]{2}{*}{ Alpha } & $0.031 \%$ & $0.075 \%$ & $0.102 \%$ & $0.076 \%$ & $0.084 \%$ & $0.052 \%$ \\
\hline & {$[0.35]$} & {$[0.84]$} & {$[1.40]$} & {$[0.87]$} & {$[0.88]$} & {$[0.45]$} \\
\hline \multirow[t]{2}{*}{ Rm-Rf } & 0.963 & 0.897 & 0.926 & 0.886 & 0.945 & 1.112 \\
\hline & {$[39.21]$} & {$[37.56]$} & {$[46.99]$} & {$[37.40]$} & {$[36.42]$} & {$[35.84]$} \\
\hline \multirow[t]{2}{*}{ SMB } & -0.244 & -0.272 & -0.170 & -0.289 & -0.118 & 0.143 \\
\hline & {$[5.87]$} & {$[6.73]$} & {$[5.10]$} & {$[7.20]$} & {$[2.70]$} & {$[2.71]$} \\
\hline \multirow[t]{2}{*}{ HML } & 0.047 & 0.158 & 0.072 & 0.177 & 0.107 & -0.215 \\
\hline & {$[1.19]$} & {$[4.12]$} & {$[2.29]$} & {$[4.66]$} & {$[2.56]$} & {$[4.32]$} \\
\hline \multirow[t]{2}{*}{ MOM } & -0.045 & -0.060 & -0.066 & -0.062 & -0.077 & -0.091 \\
\hline & {$[2.18]$} & {$[2.97]$} & {$[3.99]$} & {$[3.11]$} & {$[3.53]$} & {$[3.47]$} \\
\hline Adj. R-sqr & 0.928 & 0.926 & 0.952 & 0.926 & 0.925 & 0.923 \\
\hline \multicolumn{7}{|c|}{ Panel B: $2002-2007(\mathrm{~N}=66)$} \\
\hline \multirow[t]{2}{*}{ Alpha } & $0.005 \%$ & $0.019 \%$ & $0.048 \%$ & $0.018 \%$ & $0.003 \%$ & $0.247 \%$ \\
\hline & {$[0.03]$} & {$[0.15]$} & {$[0.43]$} & {$[0.15]$} & {$[0.02]$} & {$[1.76]$} \\
\hline \multirow[t]{2}{*}{ Rm-Rf } & 0.978 & 0.871 & 0.903 & 0.853 & 0.932 & 1.113 \\
\hline & {$[18.35]$} & {$[18.66]$} & {$[21.76]$} & {$[18.55]$} & [17.33] & {$[21.51]$} \\
\hline \multirow[t]{2}{*}{ SMB } & -0.285 & -0.340 & -0.188 & -0.365 & -0.162 & 0.133 \\
\hline & {$[4.20]$} & {$[5.73]$} & {$[3.55]$} & {$[6.25]$} & {$[2.37]$} & {$[2.02]$} \\
\hline \multirow[t]{2}{*}{ HML } & 0.006 & 0.024 & -0.013 & 0.068 & -0.158 & -0.027 \\
\hline & {$[0.08]$} & {$[0.35]$} & {$[0.20]$} & {$[0.99]$} & {$[1.94]$} & {$[0.35]$} \\
\hline \multirow[t]{2}{*}{$\mathrm{MOM}$} & 0.000 & -0.084 & -0.080 & -0.084 & -0.058 & 0.038 \\
\hline & {$[0.00]$} & {$[2.33]$} & {$[2.51]$} & {$[2.38]$} & {$[1.39]$} & {$[0.95]$} \\
\hline Adj. R-sqr & 0.881 & 0.895 & 0.923 & 0.893 & 0.884 & 0.923 \\
\hline \multicolumn{7}{|c|}{ Panel C: $2008-2015(\mathrm{~N}=96)$} \\
\hline \multirow[t]{2}{*}{ Alpha } & $0.044 \%$ & $0.155 \%$ & $0.166 \%$ & $0.153 \%$ & $0.198 \%$ & $-0.165 \%$ \\
\hline & {$[0.37]$} & {$[1.30]$} & {$[1.71]$} & [1.30] & [1.64] & [1.09] \\
\hline \multirow[t]{2}{*}{ Rm-Rf } & 0.960 & 0.894 & 0.926 & 0.887 & 0.935 & 1.140 \\
\hline & [33.66] & [31.66] & {$[40.25]$} & {$[31.50]$} & {$[32.54]$} & {$[31.52]$} \\
\hline \multirow[t]{2}{*}{ SMB } & -0.222 & -0.211 & -0.149 & -0.221 & -0.080 & 0.128 \\
\hline & {$[4.07]$} & {$[3.91]$} & {$[3.38]$} & {$[4.10]$} & {$[1.45]$} & {$[1.84]$} \\
\hline \multirow[t]{2}{*}{ HML } & 0.044 & 0.215 & 0.107 & 0.221 & 0.198 & -0.367 \\
\hline & {$[0.89]$} & {$[4.42]$} & {$[2.71]$} & {$[4.56]$} & {$[4.01]$} & [5.91] \\
\hline \multirow[t]{2}{*}{ MOM } & -0.059 & -0.036 & -0.053 & -0.042 & -0.061 & -0.170 \\
\hline & {$[2.33]$} & {$[1.45]$} & {$[2.60]$} & [1.69] & [2.39] & {$[5.30]$} \\
\hline Adj. R-sqr & 0.942 & 0.940 & 0.961 & 0.940 & 0.945 & 0.938 \\
\hline
\end{tabular}


Table 6: Portfolios' Alphas and Idiosyncratic Risk Comparison

This table reports the tests for difference in alphas $\left(\alpha_{1}-\alpha_{2}\right.$; in percentage points) and in idiosyncratic risks $\left(s_{1}^{2} / s_{2}^{2}\right)$ for the gender diverse portfolios. The sample period is from 2002 to 2015. SHE mimics SSGA's ETF with ticker SHE, $H E$ is created here to contrast $S H E, W O B$ mimics MSCI Women on Board Index, US2020 is a campaign led by Sonnabend (2015), MSParity mimics Morgan Stanley Parity Portfolio and WIL mimics Barclays Women In Leadership ETN.

Panel A: Paired Student's t-test $\left(H_{0}: \alpha_{1=\text { row }}-\alpha_{2=\text { column }}=0\right)$

\begin{tabular}{|c|c|c|c|c|c|}
\hline & SHE & WOB & MSParity & US2020 & WIL \\
\hline $\mathrm{HE}$ & 0.02 & -0.02 & -0.02 & -0.05 & -0.03 \\
\hline (p-value) & $(0.90)$ & $(0.89)$ & $(0.88)$ & $(0.75)$ & $(0.84)$ \\
\hline \multirow[t]{2}{*}{$\mathrm{SHE}$} & & -0.04 & -0.05 & -0.07 & -0.05 \\
\hline & & $(0.62)$ & $(0.60)$ & $(0.40)$ & $(0.55)$ \\
\hline \multirow[t]{2}{*}{ WOB } & & & 0.00 & -0.03 & -0.01 \\
\hline & & & $(0.87)$ & $(0.60)$ & $(0.86)$ \\
\hline \multirow[t]{2}{*}{ MSParity } & & & & -0.03 & -0.01 \\
\hline & & & & $(0.63)$ & $(0.89)$ \\
\hline \multirow[t]{2}{*}{ US2020 } & & & & & 0.02 \\
\hline & & & & & $(0.76)$ \\
\hline
\end{tabular}

Panel B: Chi-square Variance Test $\left(H_{0}: s_{1=\text { row }}^{2} / s_{2=\text { column }}^{2}=1\right)$

\begin{tabular}{|c|c|c|c|c|c|}
\hline & SHE & WOB & MSParity & US2020 & WIL \\
\hline $\mathrm{HE}$ & 1.60 & 1.69 & 1.72 & 2.48 & 1.43 \\
\hline (p-value) & $(0.00)$ & $(0.00)$ & $(0.00)$ & $(0.00)$ & $(0.02)$ \\
\hline \multirow[t]{2}{*}{ SHE } & & 1.06 & 1.07 & 1.55 & 0.90 \\
\hline & & $(0.73)$ & $(0.65)$ & $(0.01)$ & $(0.48)$ \\
\hline \multirow[t]{2}{*}{ WOB } & & & 1.02 & 1.47 & 0.85 \\
\hline & & & $(0.92)$ & $(0.02)$ & $(0.29)$ \\
\hline \multirow[t]{2}{*}{ MSParity } & & & & 1.45 & 0.83 \\
\hline & & & & $(0.02)$ & $(0.25)$ \\
\hline \multirow[t]{2}{*}{ US2020 } & & & & & 0.58 \\
\hline & & & & & $(0.00)$ \\
\hline
\end{tabular}


Table 7: Firm's Idiosyncratic Risk and Female Leadership Ratio

This table reports results for the Fama-MacBeth regression. The sample period is from 2002 to 2015. Every year, we first run individual Carhart four factor model to obtain firm-specific idiosyncratic volatility $\left(\varepsilon_{i, t}\right)$ for firm $i$ in year $t$. The individual firm's idiosyncratic volatility is calculated by IdioVol $l_{i, t}=\sqrt{12} \times \operatorname{Std}\left(\varepsilon_{i, t}\right) . \quad \beta^{M k t R f}$ is the coefficient of market premium, $\beta^{S M B}$ is the coefficient of size premium, $\beta^{H M L}$ is the coefficient of firm prospective premium, and $\beta^{M O M}$ is the coefficient of momentum. We consider two versions of FemaleRatio: the first one is the ratio of female board members to total board members; the other one is the ratio of female board members and senior managers to total board members and senior managers. The corresponding $t$-statistics are reported in [ ].

\begin{tabular}{|c|c|c|c|c|}
\hline \multirow[b]{3}{*}{ Constant } & \multicolumn{4}{|c|}{ Dep. Variable: Idiosyncratic Volatility } \\
\hline & \multicolumn{2}{|c|}{ Board \& senior mgt } & \multicolumn{2}{|c|}{ Board only } \\
\hline & 0.206 & 0.215 & 0.209 & 0.216 \\
\hline & {$[22.80]$} & [25.04] & {$[22.47]$} & {$[23.40]$} \\
\hline \multirow[t]{2}{*}{$\beta^{M k t R f}$} & 0.026 & 0.026 & 0.026 & 0.026 \\
\hline & {$[1.38]$} & {$[1.37]$} & {$[1.38]$} & {$[1.37]$} \\
\hline \multirow[t]{2}{*}{$\beta^{S M B}$} & 0.019 & 0.018 & 0.019 & 0.018 \\
\hline & {$[8.21]$} & {$[8.15]$} & {$[8.22]$} & {$[8.13]$} \\
\hline \multirow[t]{2}{*}{$\beta^{H M L}$} & 0.014 & 0.014 & 0.014 & 0.014 \\
\hline & {$[1.31]$} & {$[1.32]$} & {$[1.31]$} & {$[1.32]$} \\
\hline \multirow[t]{2}{*}{$\beta^{M O M}$} & -0.017 & -0.017 & -0.017 & -0.017 \\
\hline & {$[1.33]$} & {$[1.35]$} & {$[1.34]$} & {$[1.34]$} \\
\hline \multirow[t]{2}{*}{ Female Ratio (t-1) } & -0.101 & -0.325 & -0.120 & -0.292 \\
\hline & {$[6.80]$} & [14.31] & [11.34] & [13.61] \\
\hline \multirow[t]{2}{*}{ Female Ratio $^{2}(\mathrm{t}-1)$} & & 0.757 & & 0.560 \\
\hline & & {$[9.94]$} & & {$[6.12]$} \\
\hline Avg. R-sqr & 0.237 & 0.243 & 0.239 & 0.243 \\
\hline $\mathrm{N}$ & 18,197 & & & \\
\hline
\end{tabular}


Table 8: Firm's Idiosyncratic Risk and Corporate Social Responsibility Score

This table reports the results for two-stage least square regression. The sample period is from 2002 to 2015. The dependent variable is the annualized standard deviation of the residuals from Carhart four factor Model $\left(\operatorname{IdioV}_{i, t}=\sqrt{12} \times \operatorname{Std}\left(\varepsilon_{i, t}\right)\right)$. We use two instrumental variables to proxy female ratios: the first one is KLD ESG ALL score, and the second one is the the KLD ESG DIV score (both are adjusted by removing board diversity indicators), controlling for firm characteristics which include the logarithmic of firm's market capitalization, board size, ROA, leverage, sales, and dividend. $\beta^{M k t R f}$ is the coefficient of market premium, $\beta^{S M B}$ is the coefficient of size premium, $\beta^{H M L}$ is the coefficient of firm prospective premium, and $\beta^{M O M}$ is the coefficient of momentum. We consider two different FemaleRatio: the first one is the ratio of female board members to total board members; the other one is the ratio of female board members and senior managers to total board members and senior managers. The corresponding $t$-statistics are reported in [ ].

\begin{tabular}{|c|c|c|c|c|}
\hline \multirow{3}{*}{ Constant } & \multicolumn{4}{|c|}{ Dep. Variable: Idiosyncratic Volatility } \\
\hline & \multicolumn{2}{|c|}{ Board \& senior mgt } & \multicolumn{2}{|c|}{ Board only } \\
\hline & 0.321 & 0.283 & 0.323 & 0.288 \\
\hline & {$[35.38]$} & {$[37.57]$} & {$[37.90]$} & [39.43] \\
\hline \multirow[t]{2}{*}{$\beta^{M k t R f}$} & 0.005 & 0.005 & 0.005 & 0.005 \\
\hline & {$[6.19]$} & {$[6.78]$} & {$[6.12]$} & {$[6.70]$} \\
\hline \multirow[t]{2}{*}{$\beta^{S M B}$} & 0.008 & 0.008 & 0.008 & 0.008 \\
\hline & {$[13.75]$} & {$[14.81]$} & {$[13.41]$} & [14.53] \\
\hline \multirow[t]{2}{*}{$\beta^{H M L}$} & 0.003 & 0.003 & 0.003 & 0.003 \\
\hline & {$[6.50]$} & {$[6.68]$} & {$[6.69]$} & {$[6.82]$} \\
\hline \multirow{2}{*}{$\beta^{M O M}$} & -0.001 & -0.000 & -0.001 & -0.001 \\
\hline & {$[0.96]$} & {$[0.63]$} & {$[1.14]$} & {$[0.79]$} \\
\hline \multirow[t]{2}{*}{ IV: ALL (t-1) } & -0.731 & & -0.742 & \\
\hline & [14.84] & & [17.20] & \\
\hline \multirow[t]{2}{*}{ IV: DIV (t-1) } & & -0.448 & & -0.482 \\
\hline & & {$[12.81]$} & & {$[15.14]$} \\
\hline Adj. R-sqr & 0.043 & 0.138 & 0.035 & 0.131 \\
\hline $\mathrm{N}$ & 13,689 & & & \\
\hline
\end{tabular}


Table 9: First Difference Regression of KLD ESG Score on Female Board Ratio

This table reports the regression results, with fixed sector and year effect. The sample period is from 2002 to 2015 . $\Delta$ is the yearly difference.FemaleBdRatio ${ }_{i, t-1}$ is the lagged female board ratio. The dependent variables are the KLD ESG scores, viz. Environment (ENV), Community (COM), Human Rights (HUM), Employee (EMP), Diversity (DIV), Product (PRO), and Governance (GOV). ALL is the sum of all KLD ESG sub category scores. The corresponding $t$-statistics are reported in [ ].

\begin{tabular}{|c|c|c|c|c|c|c|c|c|}
\hline & \multicolumn{8}{|c|}{ Dep. Variable: $\triangle$ KLD ESG Score } \\
\hline & ALL & ENV & $\mathrm{COM}$ & HUM & EMP & DIV & $\mathrm{PRO}$ & GOV \\
\hline \multirow[t]{2}{*}{ Constant } & -0.346 & -0.067 & 0.014 & -0.020 & -0.063 & 0.024 & -0.031 & -0.204 \\
\hline & {$[5.33]$} & {$[2.85]$} & {$[0.92]$} & {$[2.39]$} & {$[1.96]$} & {$[0.96]$} & {$[1.73]$} & {$[8.40]$} \\
\hline \multirow{2}{*}{$\Delta \mathrm{LN}($ MarketCap) } & -0.119 & -0.033 & -0.049 & -0.017 & 0.036 & -0.036 & 0.001 & -0.020 \\
\hline & [2.63] & {$[2.01]$} & {$[4.62]$} & {$[3.01]$} & {$[1.61]$} & [2.04] & {$[0.09]$} & [1.18] \\
\hline$\Delta$ BoardSize & 0.007 & -0.011 & 0.003 & 0.001 & -0.004 & 0.014 & -0.001 & 0.005 \\
\hline \multirow[t]{2}{*}{$\Delta \mathrm{ROA}$} & 0.000 & -0.122 & 0.016 & -0.051 & 0.061 & 0.006 & 0.010 & 0.080 \\
\hline & {$[0.00]$} & {$[2.06]$} & {$[0.41]$} & {$[2.43]$} & {$[0.76]$} & {$[0.09]$} & {$[0.23]$} & {$[1.31]$} \\
\hline \multirow[t]{2}{*}{$\Delta$ Leverage } & -0.348 & 0.034 & -0.021 & -0.025 & -0.092 & 0.009 & -0.083 & -0.170 \\
\hline & [1.79] & {$[0.49]$} & {$[0.46]$} & [1.02] & {$[0.95]$} & {$[0.12]$} & {$[1.56]$} & {$[2.34]$} \\
\hline \multirow[t]{2}{*}{$\Delta$ Sales } & 0.089 & 0.066 & 0.001 & -0.006 & -0.005 & 0.011 & -0.023 & 0.044 \\
\hline & [1.03] & {$[2.11]$} & {$[0.04]$} & {$[0.50]$} & {$[0.12]$} & {$[0.33]$} & {$[0.95]$} & [1.36] \\
\hline$\Delta$ Dividend & -0.042 & 0.009 & 0.002 & 0.007 & -0.082 & -0.009 & -0.011 & 0.043 \\
\hline \multirow[t]{2}{*}{$\Delta$ FemaleBdRatio $(\mathrm{t}-1)$} & 1.071 & 0.060 & 0.095 & 0.009 & 0.324 & 0.283 & -0.097 & 0.397 \\
\hline & {$[2.80]$} & {$[0.44]$} & {$[1.05]$} & {$[0.17]$} & {$[1.71]$} & {$[1.90]$} & {$[0.93]$} & {$[2.78]$} \\
\hline Adj. R-sqr & 0.077 & 0.147 & 0.027 & 0.018 & 0.084 & 0.029 & 0.025 & 0.176 \\
\hline $\mathrm{N}$ & 11,177 & & & & & & & \\
\hline
\end{tabular}


Table 10: First Difference Regression of Female Board Ratio on KLD ESG Scores

This table reports the regression results, with fixed sector and year effect. The sample period is from 2002 to 2015. $\Delta$ is the yearly difference. Scores are the KLD ESG scores, viz. Environment (ENV), Community (COM), Human Rights (HUM), Employee (EMP), Diversity (DIV), Product (PRO), and Governance (GOV). ALL is the sum of all KLD ESG sub category scores. The dependent variable is the female board ratio in the next year $\left(\right.$ FemaleBdRatio $\left._{i, t+1}\right)$. The corresponding $t$-statistics are reported in [ ].

\begin{tabular}{lrrrrrrrr}
\hline & \multicolumn{7}{c}{ Dep. Variable: $\Delta$ Female Board Ratio $(\mathrm{t}+1)$} \\
\cline { 2 - 9 } & ALL & ENV & COM & HUM & EMP & DIV & PRO & GOV \\
\hline Constant & 0.009 & 0.009 & 0.009 & 0.009 & 0.009 & 0.009 & 0.009 & 0.009 \\
$\Delta$ LN(MarketCapØ9.001 & {$[4.85]$} & {$[4.85]$} & {$[4.85]$} & {$[4.82]$} & {$[4.87]$} & {$[4.83]$} & {$[4.85]$} \\
& {$[1.24]$} & {$[1.27]$} & {$[1.30]$} & {$[1.23]$} & {$[1.23]$} & {$[1.21]$} & {$[1.23]$} & {$[1.23]$} \\
$\Delta$ BoardSize & -0.001 & -0.001 & -0.001 & -0.001 & -0.001 & -0.001 & -0.001 & -0.001 \\
& {$[2.27]$} & {$[2.24]$} & {$[2.28]$} & {$[2.27]$} & {$[2.27]$} & {$[2.25]$} & {$[2.27]$} & {$[2.27]$} \\
$\Delta$ ROA & 0.011 & 0.011 & 0.011 & 0.011 & 0.011 & 0.011 & 0.011 & 0.011 \\
& {$[2.77]$} & {$[2.81]$} & {$[2.76]$} & {$[2.77]$} & {$[2.77]$} & {$[2.77]$} & {$[2.77]$} & {$[2.77]$} \\
$\Delta$ Leverage & 0.011 & 0.011 & 0.011 & 0.011 & 0.011 & 0.011 & 0.011 & 0.011 \\
& {$[2.32]$} & {$[2.30]$} & {$[2.32]$} & {$[2.31]$} & {$[2.31]$} & {$[2.31]$} & {$[2.30]$} & {$[2.32]$} \\
$\Delta$ Sales & 0.004 & 0.003 & 0.004 & 0.004 & 0.004 & 0.004 & 0.004 & 0.004 \\
& {$[1.68]$} & {$[1.65]$} & {$[1.69]$} & {$[1.69]$} & {$[1.69]$} & {$[1.69]$} & {$[1.68]$} & {$[1.68]$} \\
$\Delta$ Dividend & 0.006 & 0.006 & 0.006 & 0.006 & 0.006 & 0.006 & 0.006 & 0.006 \\
& {$[0.80]$} & {$[0.80]$} & {$[0.80]$} & {$[0.80]$} & {$[0.80]$} & {$[0.80]$} & {$[0.80]$} & {$[0.80]$} \\
$\Delta$ Score & 0.000 & 0.001 & 0.002 & 0.000 & -0.000 & -0.000 & -0.001 & 0.000 \\
& {$[0.70]$} & {$[1.91]$} & {$[1.85]$} & {$[0.23]$} & {$[0.23]$} & {$[0.85]$} & {$[0.61]$} & {$[0.44]$} \\
\hline Adj. R-sqr & 0.005 & 0.005 & 0.005 & 0.005 & 0.005 & 0.005 & 0.005 & 0.005 \\
N & 11,924 & & & & & & & \\
\hline
\end{tabular}


Table 11: Poisson Regression of Strength and Concern against Female Board Ratio

This table reports the results for Poisson regression in terms of KLD ESG strength and concern ratings. The sample period is from 2002 to 2015. The dependent variable of the Poisson regression is the strength or concern ratings in KLD ALL and its seven categories, viz. environment (ENV), communication (COM), human rights (HUM), employee (EMP), diversity (DIV), product $(\mathrm{PRO})$, and corporate governance (GOV). We only report the loadings on FemaleBdRatio ${ }_{t-1}$; other control variables are not reported to conserve space. The control variables include the lagged dependent variable $\left(y_{i, t-1}\right)$, the logarithmic of firm's market capitalization, board size, ROA, leverage, sales, and dividend. The corresponding $t$-statistics are reported in [ ].

\begin{tabular}{lrr}
\hline & Strength & Concern \\
\hline ALL & 0.171 & -0.340 \\
& {$[1.21]$} & {$[2.31]$} \\
ENV & -0.077 & -0.251 \\
& {$[0.23]$} & {$[0.62]$} \\
COM & 0.879 & -0.704 \\
& {$[2.01]$} & {$[1.01]$} \\
HUM & -0.260 & 0.007 \\
& {$[0.19]$} & {$[0.01]$} \\
EMP & 0.519 & -0.158 \\
& {$[1.82]$} & {$[0.52]$} \\
DIV & & -1.723 \\
& 0.047 & {$[4.89]$} \\
PRO & {$[0.21]$} & 0.130 \\
& 0.565 & {$[0.38]$} \\
GOV & {$[0.88]$} & -0.513 \\
& & {$[1.76]$} \\
\hline
\end{tabular}




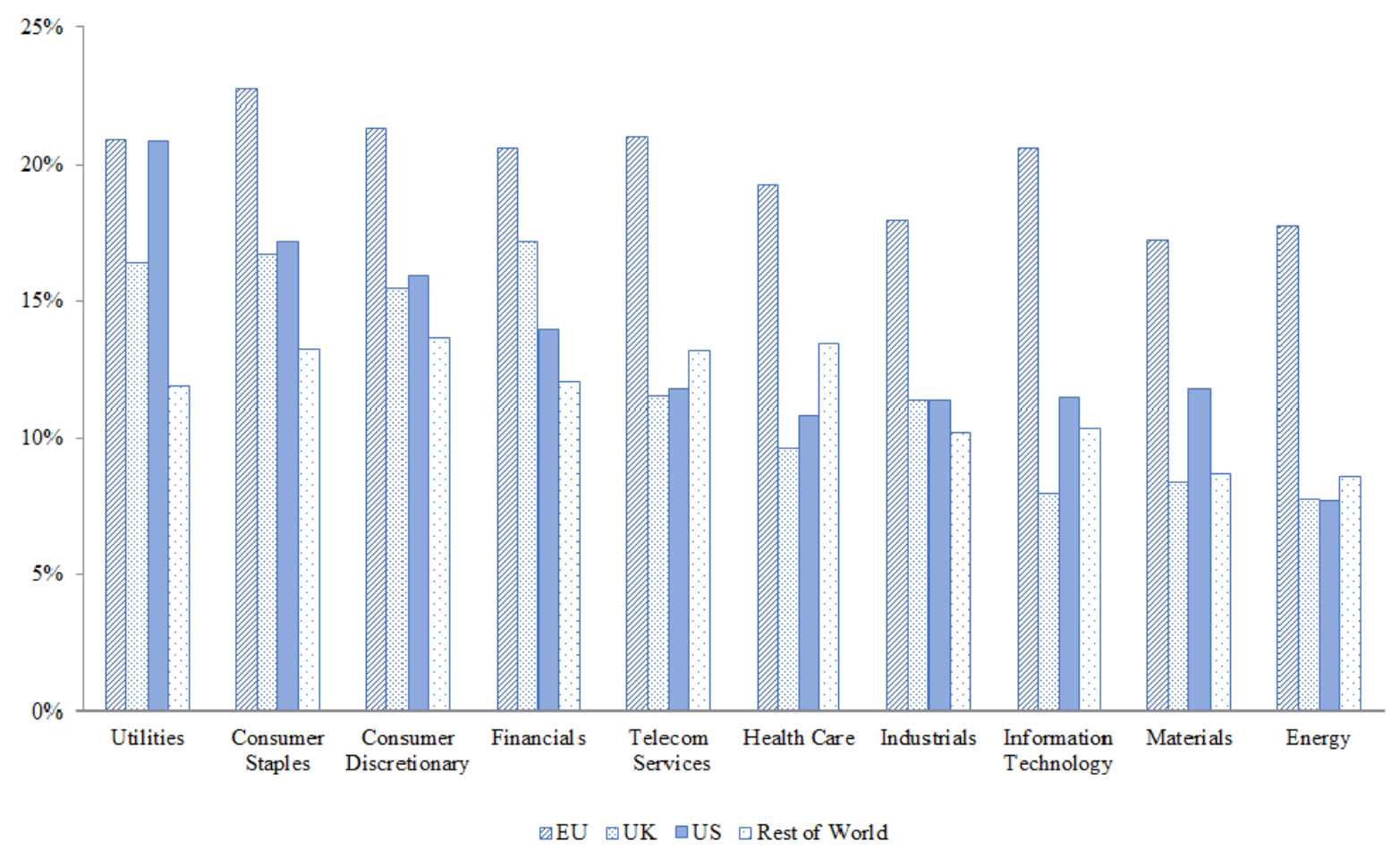

Figure 1: Average Female Board Ratio as of April 2015 


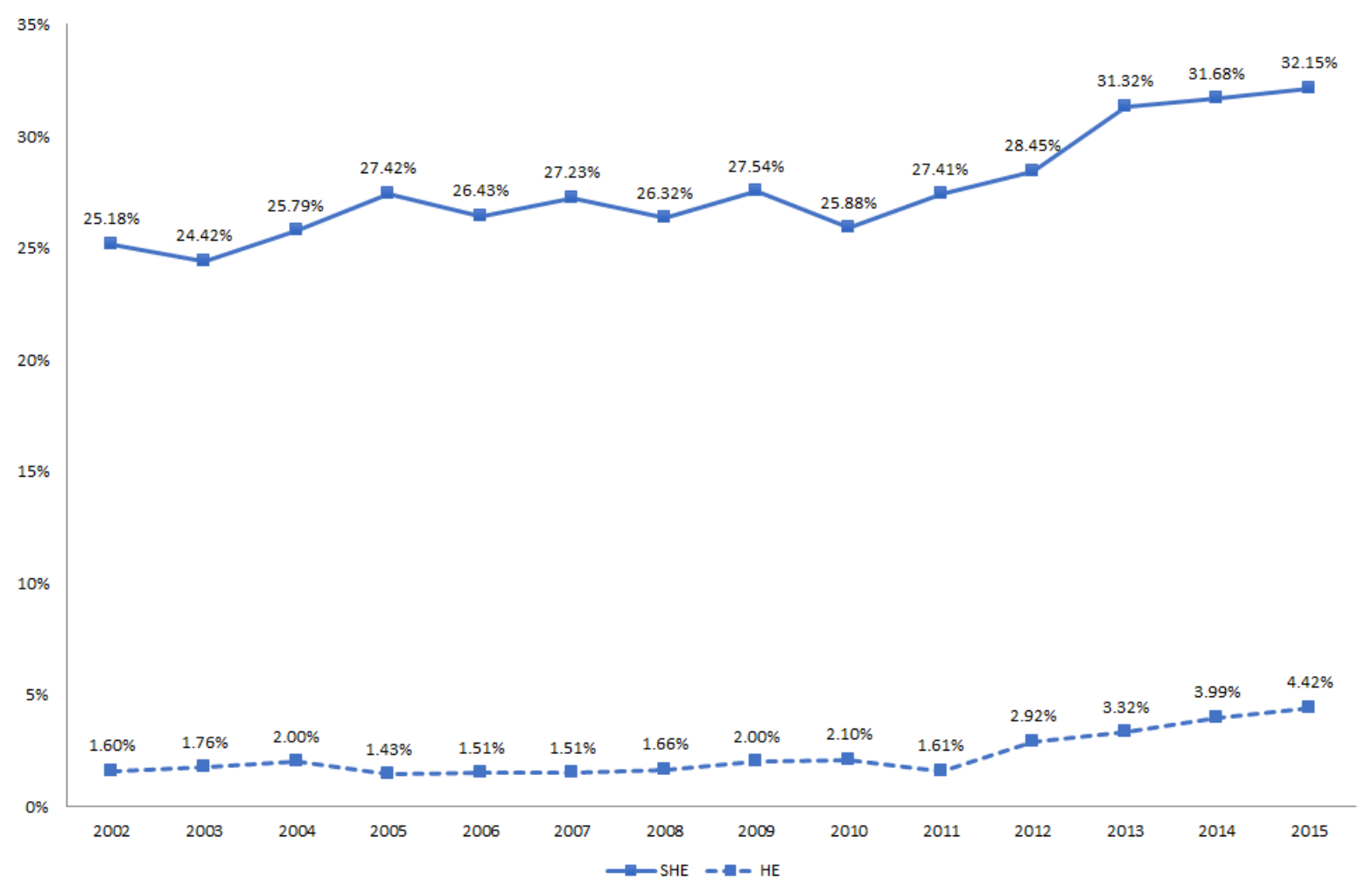

Figure 2: SHE and HE Female Board Ratio

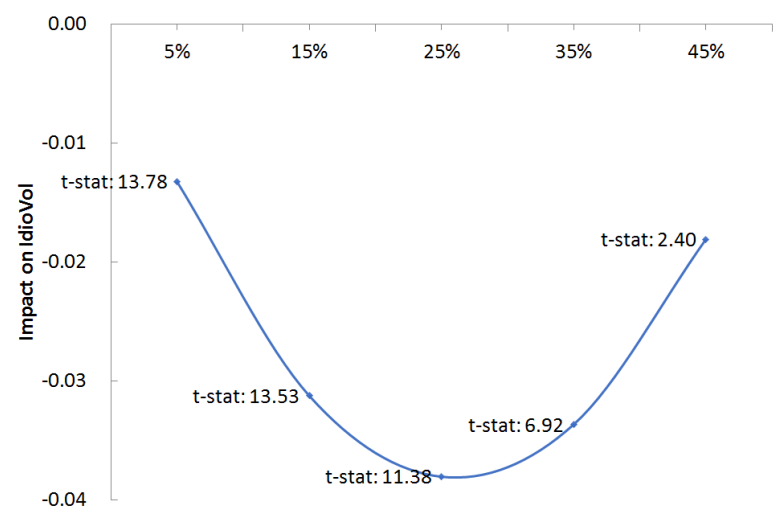

(i) Female Board Ratio

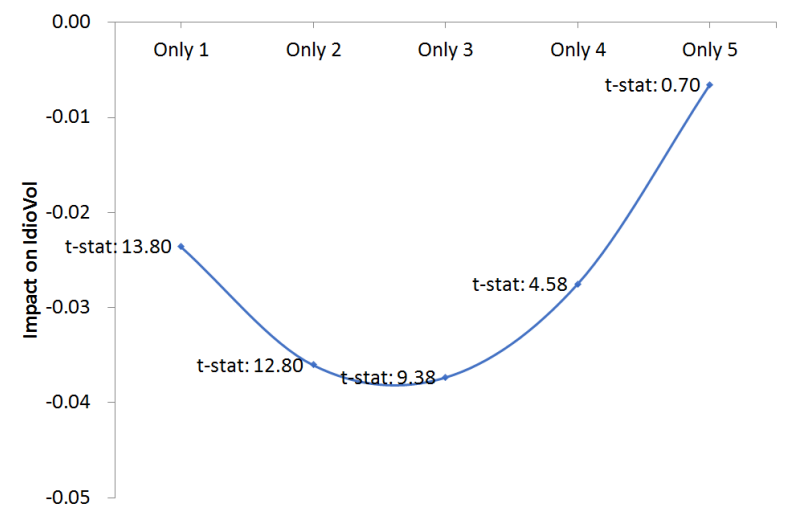

(ii) Female Board Member

Figure 3: Non-linear Relationship between Idiosyncratic Risk and Female Board Ratio 